\title{
A Comparative Analysis of the Application of the 1951 Refugee Convention to Victims of Sexual Violence in South Africa, Tanzania and Uganda
}

\section{P.E.R}

Pioneer in peer-reviewed, open access online law publications

Author

Oghenerioborue Esther Eberechi

Affiliation

University of Fort Hare

South Africa

Email rioborue@gmail.com

Date Submission

2 April 2019

Date Revised

27 May 2020

Date Accepted

22 July 2020

Date published

30 July 2020

\section{Editor Prof KD Beiter}

How to cite this article

Eberechi OE "A Comparative Analysis of the Application of the 1951 Refugee Convention to Victims of Sexual Violence in South Africa, Tanzania and Uganda" PER / PELJ 2020(23) - DOI http://dx.doi.org/10.17159/17273781/2020/v23i0a6225

\section{Copyright}

DOI http://dx.doi.org/10.17159/17273781/2020/v23i0a6225

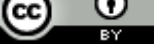

\begin{abstract}
This article seeks to ascertain whether refugees who are victims of sexual violence in contracting states enjoy access to courts per Article 16 of the United Nations (UN) Convention Relating to the Status of Refugees (1951 Refugee Convention). It does so by comparing the situation of urban refugees in South Africa with that of refugees in camps in Tanzania and settlements in Uganda, beginning with a description of what "accessing courts" entails in the respective domestic criminal justice systems and of what mechanisms are in place for addressing sexual offences. It further uses the qualitative analysis of documented prosecuted cases of sexual violence in South African, Tanzanian and Ugandan courts between 2013-2017, 2009-2016 and 2013-2017 respectively to establish if these countries prosecute cases of sexual violence suffered by their citizens and whether claims of such violations affecting refugees also enjoy the same treatment. The enquiry found that of 328 documented prosecuted cases of sexual offences in South Africa, victims who were citizens were a majority in number. In Tanzania there appeared to be few prosecuted cases of sexual violence against refugees, but given that limited documentation is available, it is difficult to assess the actual figures. In Uganda the 187 recorded prosecuted cases of sexual offences in the years of investigation all related to citizens, despite the introduction of a mobile court to refugee settlements. Overall, this paper recommends that the countries under review adopt measures to ensure the prompt prosecution of cases of sexual violence against refugees and thereby enable them to access courts and testify against their assailants.
\end{abstract}

\section{Keywords}

Access to courts; refugees; sexual violence.

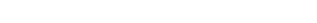




\section{Introduction}

Female refugees hosted in camps, settlements, urban areas, and reception, detention and repatriation centres ${ }^{1}$ suffer sexual violence. ${ }^{2}$ Even though sexual offences can lead to manslaughter, fatal injuries, undesired or premature gravidness, sexually transmitted diseases or infections (STD/STIs), barrenness, HIV/AIDS, cervical cancer, and venereal disease, ${ }^{3}$ most of the time the perpetrators are not held accountable. ${ }^{4}$ Victims also suffer from psychological trauma, mental health problems, ${ }^{5}$ post-traumatic stress disorders (PTSD), ${ }^{6}$ spontaneous abortions if raped and pregnant, protracted haemorrhaging, vesicovaginal and rectovaginal fistulas, insomnia, nightmares, chest and back pains, dysmenorrhea, and death resulting from unsafe abortions and suicide. ${ }^{7}$

In many instances, refugees who are victims of the sexual violence mentioned above do not have access to courts despite the provision of Article 16 of the 1951 Refugee Convention, ${ }^{8}$ which explicitly states:

1. A refugee shall have free access to the courts of law on the territory of all Contracting States.

2. A refugee shall enjoy in the Contracting State in which he has his habitual residence the same treatment as a national in matters pertaining to access to the Courts, including legal assistance and exemption from cautio judicatum solvi.

Oghenerioborue Esther Eberechi. LLB LLM (UNIBEN) LLD (UP). Postdoctoral Research Fellow, University of Fort Hare, South Africa. E-mail: oeberechi@ufh.ac.za, rioborue@gmail.com. ORCHID ID: https://orcid.org/00000002-3362-5379. This article was part of my LLD research work. The assistance of the University of Pretoria is therefore thanked and acknowledged.

1 Eberechi Access to Justice 3; https://data2.unhcr.org/en/country/uga; https://www.unicef.org/appeals/files/UNICEF_Tanzania_Humanitarian_Situation_R eport_August_2018.pdf; HRW Prohibited Persons 83-92.

2 UNHCR 1995 https://www.refworld.org/docid/3ae6b33e0.html 1.3(b)(c); Eberechi Access to Justice 6-7.

3 Eberechi Access to Justice 1; UNHCR 1995 https://www.refworld.org/docid/3ae6b33 e0.html 1.3(b)(c); UNHCR 1991 https://www.unhcr.org/publications/legal/ 3d4f915e4/guidelines-protection-refugee-women.html para 94.

$4 \quad$ Eberechi Access to Justice 6-7.

5 UNHCR 1995 https://www.refworld.org/docid/3ae6b33e0.html 1.3(b)(c); RamjiNogales 2011 Int CLR 820.

6 UNHCR 1995 https://www.refworld.org/docid/3ae6b33e0.html 1.3(b)(c); RamjiNogales 2011 Int CLR 821.

7 Mabuwa Seeking Protection 39; Vigaud-Walsh 2015 https://static1. squarespace.com/static/506c8ea1e4b01d9450dd53f5/t/5678aee07086d7cddecf1b ab/1450749707001/20151222+Tanzania.pdf 1 .

8 Convention Relating to the Status of Refugees (1951) (hereafter the 1951 Refugee Convention). 
3. A refugee shall be accorded in the matters referred to in paragraph 2 in countries other than that in which he has his habitual residence the treatment granted to a national of the country of his habitual residence. ${ }^{9}$

Article 16 provides that a refugee who requires judicial intervention in a country of refuge, in the same way as that enjoyed by that country's citizens, should be granted unhindered access to domestic courts. ${ }^{10}$ Such access includes legal aid and exemption from any cautionary fees. Article 16 stipulates that the jurisdiction for addressing the legal needs of refugees is the domestic court system of host states. As such, host states have the responsibility to respond to all human rights violations against refugees in their territories.

Generally, treaties become law if they have been ratified, signed, deposited and domesticated by parties. ${ }^{11}$ However, the countries of study differ in their application of international treaties in their internal judicial systems depending on whether they follow a monist or dualist approach,,$^{12}$ or both. In the monist approach, international law is part of municipal law and enforceable in domestic courts without any legislative enactment. ${ }^{13}$ In the dualist approach, international and municipal laws are separate legal systems, and treaties must be legislated into local law to be applicable and enforceable in national courts. ${ }^{14}$ South Africa adopts both a dualist ${ }^{15}$ and a monist system. In terms of sections 231 and 232 of the Constitution of South Africa, customary international law is applied directly to municipal law, as long as it does not contravene the provisions of the constitution or any acts of parliaments. ${ }^{16}$ Tanzania adopts an exclusively dualist system. ${ }^{17}$ Uganda,

9

10 Articles 16(1) and (2) of the 1951 Refugee Convention.

11

12

13

14

15

17

1951 Refugee Convention.

Jennings and Watts Oppenheim's International Law 53.

Jenings and Watts Oppenheim's International Law 53. Snyman 2014 PELJ 1471.

15 (CC) para 88. be law in the country.

Articles 11-16 of the Vienna Convention on the Law of Treaties (1969).

Jennings and Watts Oppenheim's International Law 53; Ferreira and Ferreira-

Eberechi Access to Justice 201-202; s 231(2)(3) of the Constitution of the Republic of South Africa,1996 (hereafter the Constitution) provides that "an international agreement binds the republic only after it has been approved by a resolution in both the National Assembly and the National Council of Provinces, unless it is an agreement referred to in sub-section (3)". S 39(1)(b) of the Constitution; S v Makwanyane 19953 SA 391 (CC) para 35; Ferreira and Ferreira-Snyman 2014 PELJ 1477; Glenister v President of the Republic of South Africa 20113 SA 347

Sections $231(3)$ and 232 of the Constitution declare customary international law to

7 Eberechi Access to Justice 203; Art 63(3)(c) of the Constitution of the United Republic of Tanzania, 1977. 
too, is dualist in its approach to the application and enforcement of international treaties in its internal laws. ${ }^{18}$

South Africa, Tanzania and Uganda ratified and domesticated the 1951 Refugee Convention on 12 January 1996, 12 May 1964, and 27 September 1976 respectively. ${ }^{19}$ South Africa was host to 89,285 refugees as at mid$2018,{ }^{20}$ while Tanzania was accommodating 326,942 refugees in three refugee camps as at 31 December $2018 .{ }^{21}$ Uganda was host to $1,205,913$ refugees in more than 11 settlements as at 31 January $2019 .^{22}$ These countries reflect the hosting facilities for refugees in Africa and one can appreciate the magnitude of the problem. For instance, South Africa does not host refugees in camps or settlements, which means that refugees are living amongst the citizens - a more liberal type of hosting, ${ }^{23}$ while Tanzania and Uganda host refugees in camps and settlements respectively. ${ }^{24}$ By virtue of their incorporation of refugee law into their domestic laws, these countries are bound to fulfil their obligation to grant refugees who are victims of sexual violence access to court just as they do their citizens who suffer sexual violence.

The question to be considered in this article is: Do refugees who are victims of sexual violence have free access to courts in contracting states? In attemptong to arrive at an answer, the article first enquires retrospectively whether nationals of these countries who are victims of sexual violence have free access to court, which it does by analysing laws, criminal procedures and decided cases and examining how these countries handle cases of sexual violence involving their citizens, in comparison with

18 Eberechi Access to Justice 203-204; Art XXVIII(i)(a)(b) of the Constitution of the Republic of Uganda, 1995; Ratification of Treaties Act, 1998 (Cap 204); Wethered $v$ Calcutt (1842) 4 Man \& G 566; Concorp International Ltd vs East and Southern Development Bank 2010 UGSC 19 (18 October 2010); Obitre-Gama 2000 https://www.who.int/tobacco/media/en/JUDY2000X.pdf.

19 UNHCR 2016 https://www.unhcr.org/protect/PROTECTION/3b73b0d63.pdf; Protocol Relating to the Status of Refugees (1967). UNHCR 2018 https://www.unhcr.org/afr/statistics/unhcrstats/5c52ea084/mid-yeartrends-2018.html.

21 UNICEF 2018 https://www.unicef.org/appeals/files/UNICEF_Tanzania_Humani tarian_Situation_Report_August_2018.pdf.

22 UNHCR 2019 https://data2.unhcr.org/en/country/uga.

23 Section 18(6) of the Refugees Amendment Act 11 of 2017 provides that refugees may be assessed in accordance with the ability for sustain themselves, while ss $18(7)$ and $18(8)(b)$ of the Refugees Amendment Act provide that the UNHCR or NGOs may provide shelter for indigent refugees. This shows that the government of South Africa does not in itself provide shelter for refugees.

24 Obodoruku "Multiculturalism of Tanzanian Refugees" 29, 31; Obodoruku Human Information Behavior 137; Dawa 2019 https://www.accord.org.za/conflicttrends/conflict-dynamics-in-the-bidibidi-refugee-settlement-in-uganda/. 
refugees who suffer the same fate in their countries. This article further undertakes a comparative analysis of the treatment received by refugees in South Africa, Tanzania and Uganda to ascertain whether there is compliance with Article 16 of the 1951 Refugee Convention.

\section{The problem of sexual violence against refugees ${ }^{25}$}

Sexual violence against women in South Africa is rife, but its incidence amongst migrant women is even higher due to the inadequacy of state policy in preventing and combating it. ${ }^{26}$ Refugees who suffer sexual violence in South Africa, seldom report these incidents for fear of not being taken seriously by the authorities. ${ }^{27}$

Similarly, refugees in Tanzania live in fear of rape, sexual harassment and other forms of sexual violence while away from home for several hours a day as they source firewood for cooking ${ }^{28}$ or go in search of food due to the inadequate supply of food items in the camps. ${ }^{29}$ If the have been raped, the women have unwanted pregnancies and are jilted by their suitors. ${ }^{30}$ Documentation and statistics regarding the incidence of sexual violence are scarce, but they reported a total of 319 new cases in all camps in October $2016 .{ }^{31}$

Refugees in Uganda also suffer sexual abuse and exploitation, rape, defilement, early and forced marriages. ${ }^{32}$ Although it is more prevalent among women and girls, sexual violence is also common among men and boys in refugee settlements. ${ }^{33}$ The data are again inaccurate owing to the non-reporting of certain cases, ${ }^{34}$ but by the end of December 2018 they recorded, 1,152 cases of rape, 351 of forced and early marriage, and 254 of sexual assault. ${ }^{35}$ These human rights violations occurr as a result of there being insufficient security lighting in the settlements; limited funding for

\footnotetext{
$25 \quad$ Note that these statistics are not exhaustive.

26 FIDH 2008 https://www.fidh.org/IMG/pdf/za486a.pdf.

27 Doctors Without Borders 2010 https://www.doctorswithoutborders.org/what-wedo/news-stories/research/lives-survival-migrants-and-refugees-south-africa. Obodoruku "Multiculturalism of Tanzanian Refugees" 29, 31; Obodoruku Human Information Behavior 137. Obodoruku Human Information Behavior 17, 22.

Obodoruku Human Information Behavior 23.

UNHCR 2016 https://data2.unhcr.org/en/documents/download/526012.

UNHCR 2018 https://data2.unhcr.org/en/documents/download/66524 5; UNHCR Uganda 2014 https://data2.unhcr.org/es/documents/download/48494.

UNHCR 2018 https://data2.unhcr.org/en/documents/download/66524 6; UNHCR Uganda 2014 https://data2.unhcr.org/es/documents/download/48494.

34 UNHCR 2018 https://data2.unhcr.org/en/documents/download/66524 5. 
prevention and response; a limited police presence; ${ }^{36}$ alcohol abuse resulting from idleness among the male refugees; and the lack of water and firewood close to settlements, which compels refugees to trek long distances in search of these essential commodities. ${ }^{37}$ Also, owing to the scarcity of means for adults to earn a livelihood, refugees send their children to work for local people. In the course of the work they are often sexually abused. Trading sex for money and services is also prevalent as a means of survival. ${ }^{38}$

In addition, poverty and the existence of cultural norms that downplay the importance of the girl child's education lead to secondary-school drop-out among girls, thereby contributing to early and forced child marriage and consequent sexual violence. ${ }^{39}$ Another factor predisposing towards sexual violence against refugees is the lack of occupational training and jobs for female heads of households. As a result, they suffer sexual exploitation and abuse, and they resort to survival sex. ${ }^{40}$ Recreational facilities for youths in settlements are also in short supply, leading to drunkenness and the sexual violence regularly associated with it. ${ }^{41}$

Despite the efforts of the UNHCR and its implementing partners, ${ }^{42}$ records on the incidence of sexual violence are scarce, due to under-reporting, which arises from fear of stigmatisation, humiliation and negative responses from families; the perception that sexual violence is a "private matter"; and a "lack of confidence in reporting channels". ${ }^{43}$ Furthermore, lesbian, gay, bisexual and transgender (LGBT) victims of sexual violence do not report cases given Uganda's legislation against LGBT and the negative attitudes of Ugandans towards LGBT individuals. ${ }^{44}$

Some of the perpetrators of sexual violence against refugees are familiar to the victims. They include the inhabitants of the contracting states, ${ }^{45}$ the staff

36 UNHCR 2018 https://data2.unhcr.org/en/documents/download/66524 5; Eberechi Access to Justice 5.

37 UNHCR 2018 https://data2.unhcr.org/en/documents/download/66524 5; UNHCR Uganda 2014 https://data2.unhcr.org/es/documents/download/48494.

38 UNHCR 2018 https://data2.unhcr.org/en/documents/download/66524 5; UNHCR Uganda 2014 https://data2.unhcr.org/es/documents/download/48494.

$39 \quad$ UNHCR 2018 https://data2.unhcr.org/en/documents/download/66524 6.

$40 \quad$ UNHCR 2018 https://data2.unhcr.org/en/documents/download/66524 5.

41 UNHCR 2018 https://data2.unhcr.org/en/documents/download/66524 6.

42 UNHCR 2018 https://data2.unhcr.org/en/documents/download/66524 7.

$43 \quad$ UNHCR 2018 https://data2.unhcr.org/en/documents/download/66524 5.

$44 \quad$ UNHCR 2018 https://data2.unhcr.org/en/documents/download/66524 5.

$45 \quad$ Eberechi Access to Justice 5; Mabuwa Seeking Protection 46; Vigaud-Walsh 2015 https://static1.squarespace.com/static/506c8ea1e4b01d9450dd53f5/t/5678aee070 86d7cddecf1bab/1450749707001/20151222+Tanzania.pdf 1; UNHCR 2018 
in charge of refugees, ${ }^{46}$ intimate partners, family members, teachers, influential individuals, "politicians and friends". ${ }^{47}$ Refugees also suffer sexual violence from bootleggers, ${ }^{48}$ "security forces", peace-keepers, members of law enforcement agencies and country boundary pickets. ${ }^{49}$ Amongst the sexual violence offenders against refugees are "aid employees, national and international NGOs, UN agencies, state officials and a host of others". 50

\section{Access to courts}

Access to courts is a prerequisite for an applicant to institute an action in a court of law. Considerations in this regard may include locus standi, "mootness", and the exhaustion of other legal remedies. ${ }^{51}$ The ability of a juristic person to bring a matter before a court of law encompasses the right to sue, to defend, to appear before a self-governing and unbiased court of law, and to have access to legal representation. ${ }^{52}$

Chapter Two of the South African Constitution enshrines the Bill of Rights that lists the basic rights of everyone in the country. ${ }^{53}$ Section $9(1)$ provides for equality and equal protection before the law. ${ }^{54}$ Section 34 , in turn, declares that everyone has the right to have any dispute that can be resolved by the application of law decided in a fair public hearing before a court or, where appropriate, another independent and impartial tribunal or forum. ${ }^{55}$ The Constitution provides furthermore that anyone who suffers a violation of his or her constitutional rights may seek redress at a court of competent jurisdiction. ${ }^{56}$

https://data2.unhcr.org/en/documents/download/66524 5; UNHCR Uganda 2014 https://data2.unhcr.org/es/documents/download/48494.

$46 \quad$ UNHCR 2003 https://www.unicef.org/emerg/files/gl_sgbv03.pdf 12.

47 Eberechi Access to Justice 9; UNHCR 2003 https://www.unicef. org/emerg/files/gl_sgbv03.pdf 12 .

Eberechi Access to Justice 9; The New Arab 2016 https://www.alaraby.co.uk/ english/society/2016/1/18/europe-female-migrants-refugees-face-violence-andsexual-harassment.

Eberechi Access to Justice 138; UNHCR 2003 https://www.unicef.org/ emerg/files/gl_sgbv03.pdf 15. Eberechi Access to Justice 138; UNHCR 2003 https://www.unicef.org/ emerg/files/gl_sgbv03.pdf 15.

$51 \quad$ Rathjen and Spaeth 1979 Am J Pol Sci 361.

$52 \quad$ Mandela v Minister of Prisons 19831 SA 938 (A) 957.

53 Constitution of the Republic of South Africa, 1996.

54 Section 9 of the Constitution.

$55 \quad$ Section 34 of the Constitution.

56 Section 38 of the Constitution. 
For the victim of a crime to have access to courts in criminal proceedings, the victim or complainant needs to lay charges against the offender with the police, whose responsibility it is to avert, combat or "investigate crime ..." and to defend and carry out the law. ${ }^{57}$ If upon investigation the police officer believes the testimony of the complainant, the suspect is arrested and taken into custody for further investigation. ${ }^{58}$ The law requires that a suspect be taken before a court of competent jurisdiction for a bail hearing not more than 48 hours after the arrest. ${ }^{59}$

Continued access to courts for a victim of crime is dependent on the prosecution of the case by the Director of Public Prosecution, who prosecutes the suspect on behalf of the state. ${ }^{60}$ Thus, if the prosecutor decides not to prosecute, a victim of crime will not have the opportunity to access courts to testify as to the guilt of the assailant.

In South Africa the Thuthuzela Care Centre simplifies court access for victims of rape, in particular. It is a multidisciplinary facility run by the National Prosecution Authority's (NPA's) Sexual Offences and Community Affairs Unit (SOCA). Branches have been established near communities with a high prevalence of rape, as have courts, police stations and medical facilities intended to cater for the needs of victims of sexual violence. ${ }^{61}$ Thuthuuzela is the Xhosa word for "comfort". The purpose of the organisation is to assist the victims of rape in South Africa, and branches are located in all provinces as a response to the prevalence of the scourge of rape. ${ }^{62}$

It is aimed at protecting victims against secondary trauma, the prevention of victimisation, and the improvement of the conviction rate. ${ }^{63}$ Some of the services it provides include medical examination and the collection of evidence, interviewing and counselling, the treatment and prevention of sexually transmitted infections/diseases including HIV and AIDS, the safe transportation of victims to their homes, the provision of an alternate safe

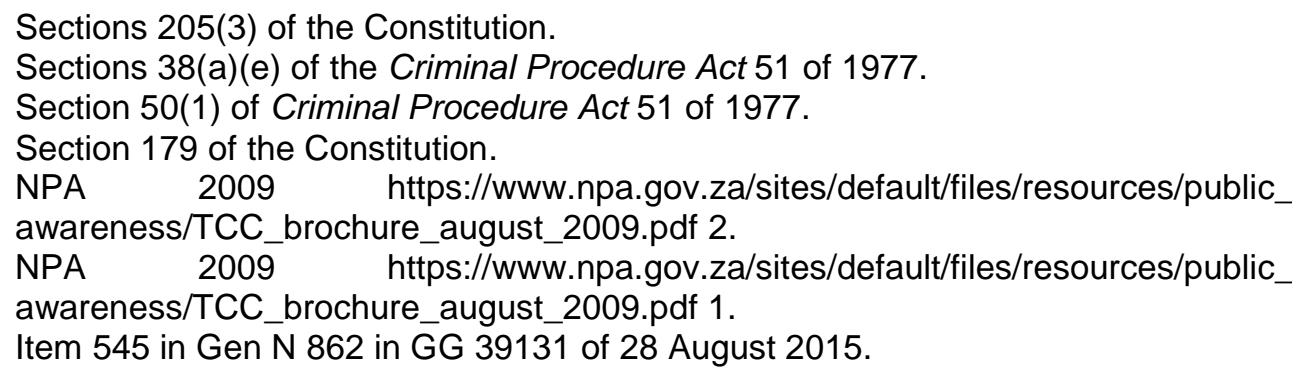


place for the victim, and the preparation of the victim for the prosecution of the case, amongst others. ${ }^{64}$

Legal Aid of South Africa is an institution that facilitates access to courts in South Africa. It is mandated to provide indigent litigants with legal advice, representation, education and information paid for by the State. ${ }^{65}$ The South African Constitution also provides for the allocation of a legal practitioner to a detained suspect at the expense of the State, to avoid injustice. ${ }^{66}$ While the Refugees Amendment Act $(2017)^{67}$ does not provide for access to courts, it does provide for appeals to the Refugee Appeals Authority against the decisions of a Refugee Status Determination officer. ${ }^{68}$

Turning to the United Republic of Tanzania, Article 13(1) of the Constitution provides for equality and equal protection before the law, without discrimination. ${ }^{69}$ Article 13(6) instructs state authorities to create facilities for the determination of the rights and duties of individuals; ensures a fair hearing; provides for the freedom to appeal against decisions by judicial and administrative institutions; and provides legal remedies against such decisions. ${ }^{70}$

In addition, the Constitution guarantees the preservation of rights as well as equality and dignity during criminal investigations and proceeding. ${ }^{71}$ However, the Refugee Act of Tanzania explicitly provides for the prosecution and punishment of refugees who are violators of the provisions of the Refugee Act and perpetrators of other unlawful acts. ${ }^{72}$ What the Act does not cater for is how a refugee or an asylum-seeker can institute criminal proceedings such as sexual violence-related offences.

Similar to South Africa and Uganda, the Tanzanian Constitution empowers the Director of Public Prosecutions to prosecute and supervise all criminal cases in the country. ${ }^{73}$ The police report to the prosecutor all verbal or written complaints received regarding all types of criminal cases, intended

\footnotetext{
$64 \quad$ NPA 2009 https://www.npa.gov.za/sites/default/files/resources/public_awareness /TCC_brochure_august_2009.pdf 7.

65 Sections 3(a), (b) and (c) of the Legal Aid South Africa Act 39 of 2014.

66 Section 35(2)(c) of the Constitution.

67 Refugees Amendment Act 11 of 2017.

68 Section 22(1) of the Refugees Amendment Act 11 of 2017.

69 Constitution of the United Republic of Tanzania, 1977.

70 Constitution of the United Republic of Tanzania, 1977.

71 Constitution of the United Republic of Tanzania, 1977.

72 Sections 24-26 of the Refugee Act 9 of 1998.

73 Article $59 \mathrm{~B}(2)$ of the Constitution of the United Republic of Tanzania, 1977; s 90(1)(a), (b) and (c) of the Criminal Procedure Act, 1985 (Cap 20); s 9(1)(a)(e) of the National Prosecutions Service Act 27 of 2008.
} 
to be committed or already committed. ${ }^{74}$ If upon investigation a police officer has enough evidence to warrant it, he or she can arrest the suspect ${ }^{75}$ and commence the procedures that lead to an apprearance in court.

This process begins with an oral or written complaint, or the presentation of an accused person to a magistrate with competent jurisdiction. Such a complaint can be made by anyone who believes the accused has committed a crime.$^{76}$ After that, a formal charge containing the alleged offence is laid and is signed by the magistrate. This leads to a preliminary hearing. ${ }^{77}$ If the formal charge does not suggest the commission of a crime, the magistrate can reject the complaint and document the reasons for the refutation. ${ }^{78}$ Conversely, where an offence exists, the complainant (the victim) is called to witness ${ }^{79}$ at the trial.

Before the trial and throughout the proceedings of the trial the defendant receives legal representation,. Without this, access to the courts would be meaningless. In Tanzania legal assistance can be applied for by any indigent individual who requires legal services in civil or criminal proceedings ${ }^{80}$ The service is not mandatory in all cases. ${ }^{81}$ Advocates and paralegals provide the service, and they guide litigants and defendants through the process of accessing the court, they educate them on their rights and how to enforce them, how to obtain legal documents, and the nature of the procedures of the court, ${ }^{82}$ and they provide legal representation 83 in the actual court proceedings.

Article 21(1) of the Ugandan Constitution provides for access to court implicitly ${ }^{84}$ by stating that everyone is equal before the law and shall enjoy equal protection before the law. Furthermore, Article 28(1) declares that every individual is entitled to a fair, prompt and public hearing before a selfgoverning, neutral court of law in the resolution of disputes relating to his or her "civil rights and obligations or any criminal charge". ${ }^{85}$ Likewise, Article

74 Section 7(1)(a) of the Criminal Procedure Act, 1985 (Cap 20); s 9(1)(a)(e) of the National Prosecutions Service Act 27 of 2008.

75 Section 10(1)(a) of the Criminal Procedure Act, 1985 (Cap 20).

76 Sections 128(1), (2) and (4) of the Criminal Procedure Act, 1985 (Cap 20).

77 Sections 128(5) and (6) of the Criminal Procedure Act, 1985 (Cap 20).

78 Section 129 of the Criminal Procedure Act, 1985 (Cap 20).

79 Section 142(1) of the Criminal Procedure Act, 1985 (Cap 20).

80 Sections 21(1), 27 and 33 of the Legal Aid Act 1 of 2017.

81 Section 33 of the Legal Aid Act 1 of 2017.

82 Section 20 of the Legal Aid Act 1 of 2017.

83 Moses Muhagama Laurance $v$ The Government of Zanzibar 2003 TZCA 3 (31 October 2003) 3,12-13.

84 Constitution of the Republic of Uganda, 1995.

85 Constitution of the Republic of Uganda, 1995. 
42 provides for fair and just treatment when appearing before an administrative tribunal and for the right to recourse to courts concerning administrative decisions made against an individual. ${ }^{86}$

Similarly, Article $50(1)^{87}$ ensures the right to seek redress in a competent court for the threat to or actual violation of the rights of a citizen, and empowers anyone who desires to seek redress in courts for the violation of his or her constitutional rights to do so. The right to engage in a class action in court is provided for in Article 50(2). ${ }^{88}$ Concerning access to the courts for refugees in the territory, section 29(h) of the Refugee Act declares that refugees are to have free access to the courts, including legal assistance under the applicable laws. ${ }^{89}$

In criminal proceedings, the power to bring cases before the courts is vested in the Director of Public Prosecution, ${ }^{90}$ who is empowered to authorise the police to investigate any criminal case, report back to him or her, and institute criminal action against an accused person or authority in a competent court, except in the event of a court-martial. ${ }^{91}$ Equally, the Director of Public Prosecution is empowered to take over criminal actions initiated by other individuals or authorities or to stop any criminal prosecution at any stage. ${ }^{92}$ The police are seized with the duty to "protect life and properties", "preserve law and order", foil and identify crime, and cooperate with the security and civilian authorities. ${ }^{93}$

\section{Sexual violence under domestic laws}

\subsection{South Africa}

South Africa's Criminal Law (Sexual Offences and Related Matters) Amendment Act ${ }^{94}$ prohibits a range of sexual acts, including rape and "compelled rape", ${ }^{95}$ sexual assault, compelled sexual assault and

\footnotetext{
86 Constitution of the Republic of Uganda, 1995.

87 Constitution of the Republic of Uganda, 1995.

88 Constitution of the Republic of Uganda, 1995.

89 Ugandan Refugee Act 21 of 2006; ss 23 and 25(a) of the Advocates (Legal Aid to Indigent Persons) Regulations, 2007.

90 Article 120 of the Constitution of the Republic of Uganda, 1995.

91 Articles 120(3)(a) and (b) of the Constitution of the Republic of Uganda, 1995.

92 Articles 120(3)(c) and (d) of the Constitution of the Republic of Uganda, 1995.

93 Articles 212(a)-(d) of the Constitution of the Republic of Uganda, 1995.

$94 \quad$ Criminal Law (Sexual Offences and Related Matters) Amendment Act 32 of 2007.

95 Sections 3 and 4 of the Criminal Law (Sexual Offences and Related Matters) Amendment Act 32 of 2007.
} 
compelled self-sexual assault. ${ }^{96}$ The Act proscribes forcing or instigating individuals who are less than or older than 18 to observe sexual offences, sexual acts or self-masturbation; the exposure, exhibition or display of genital organs, anuses, female breasts, and child pornography; and engaging the sexual services of persons who are under or above the age of 18 years. ${ }^{97}$ The Act also proscribes incest, bestiality and sexual acts with a corpse. ${ }^{98}$

In addition, the Criminal Law (Sexual Offences and Related Matters) Amendment Act Amendment Act 5 of $2015^{99}$ outlaws statutory rape, statutory sexual assault, and sexual offences against persons living with disabilities. ${ }^{100}$ The Prevention and Combating of Trafficking in Persons Act also addresses sexual violence, prohibiting human trafficking for sexual exploitation, prostitution and profiting by such acts. ${ }^{101}$

The jurisdiction for the prosecution of sexual offences in South Africa is the Magistrate's Court; the proceedings of cases of sexual violence can take place in a jurisdiction other than that where the crime was committed, and under South African law there is no lapse of time for the prosecution of these offences. ${ }^{102}$ The minimum penalty for convicted sex offenders is life imprisonment; but the court can impose a lower sentence provided the Judge believes that there are important and persuasive conditions which validate the decree of a slighter punishment. Such information. ${ }^{103}$ Additional sanctions include fines, the declaration of the convict as a dangerous criminal, committal to rehabilitative institutions established by law, and correctional supervision. ${ }^{104}$

96 Sections 5, 6 and 7 of the Criminal Law (Sexual Offences and Related Matters) Amendment Act 32 of 2007.

97 Section 8, 9, 10, and 11 of the Criminal Law (Sexual Offences and Related Matters) Amendment Act 32 of 2007.

98 Sections 12,13 and 14 of the Criminal Law (Sexual Offences and Related Matters) Amendment Act 32 of 2007. Section 1 of the Criminal Law (Sexual Offences and Related Matters) Amendment Act Amendment Act 5 of 2015.

100 Sections 15 and 16 of the Criminal Law (Sexual Offences and Related Matters) Amendment Act Amendment Act 5 of 2015.

101 Section 4(1) of the Prevention and Combating of Trafficking in Persons Act 7 of 2013.

102 Levenstein v Estate of the Late Sidney Lewis Frankel 2018 ZACC 16 (14 June 2018) 89.

103 Section 51(1) of the Criminal Law Amendment Act 105 of 1997.

104 Sections 276(1)(d), (e), (f) and (h) of the Criminal Procedure Act51 of 1977. 


\subsection{Tanzania}

Tanzania prohibits sexual violence as an offence against morality listed in the Penal Code of the United Republic of Tanzania (the Penal Code). ${ }^{105}$ The Penal Code outlaws rape, attempted rape, abduction with the intent to marry or for sexual purposes, the marriage of a girl under 16 years of age against the will of her parents or guardian, with the penalty for this ranging from seven years' to life imprisonment with or without corporal punishment. ${ }^{106}$ The indecent assault of a woman or girl is also prohibited, while the attempted or actual rape of a child under 14 is punishable by life imprisonment, with or without corporal punishment. ${ }^{107}$ Furthermore, the rape of a person with a disability is punishable by 14 years in jail, a sentence that may include corporal punishment. ${ }^{108}$

Likewise, sexual relations with a 12 year-old girl is prohibited, irrespective of whether she consented to it or if the act was perpetrated by her husband or authorised by parents who gave her out for sexual purposes. ${ }^{109}$ Where a husband commits sexual violence, he will serve five years in prison, while the parents and the procurer of such an act will serve two years in prison. ${ }^{110}$ The Code outlaws the prostitution or procurement for prostitution of a person, as well as aiding, compelling or benefitting from the prostitution. ${ }^{111}$ Persons committing these offences are guilty of a misdemeanour and are subject to imprisonment with or without corporal punishment. ${ }^{112}$ The law also punishes obtaining sexual favours through threats and intimidation, ${ }^{113}$ conspiracy and inducement, and obtaining sexual favours through false pretences or fraud makes the perpetrator liable to three years' imprisonment. ${ }^{114}$ Likewise, the Code reproves the owners of premises used for purposes of sexual exploitation. ${ }^{115}$

Tanzania's anti-trafficking law penalises the trafficking of persons for sexual exploitation and the introduction of them into foreign forced marriages for the purposses of prostitution, the making of pornography, or sexual

\footnotetext{
105 Chapter XV of the Penal Code of the Republic of Tanzania, 1945 (Cap 16) (the Penal Code).

106 Sections $130-34$ of the Penal Code.

107 Sections 135 and 136 of the Penal Code.

108 Section 137 of the Penal Code.

109 Section 138(1)(2) of the Penal Code.

110 Section 138(1)(3) of the Penal Code.

111 Sections 145 and 146 of the Penal Code.

112 Sections 139 and 143 of the Penal Code.

113 Section 140 of the Penal Code.

114 Section 148 of the Penal Code.

115 Sections 141 and 142 of the Penal Code.
} 
exploitation, with a fine of between five million shillings to one hundred million shillings, or imprisonment of 2-10 years, or both as punishment. ${ }^{116}$

\subsection{Uganda}

In Uganda the trial court responsible for dealing with sexual offences is the High Court. ${ }^{117}$ The Ugandan Penal Act prohibits sexual violence under a list of offences against morality. ${ }^{118}$ Rape carries the death penalty, while attempted rape is punishable with life imprisonment, which may include corporal punishment. ${ }^{119}$ Abduction with the intent to have carnal knowledge with or to marry the victim attracts seven years in prison; ${ }^{120}$ the indecent assault of women and girls attracts 14 years in prison, which may include corporal punishment; and those who say vulgar words to women may receive a year in prison. ${ }^{121}$ Defilement and the attempted defilement of a girl under 18 years of age carries the death penalty and 18 years' imprisonment, which may include corporal punishment. ${ }^{122}$ The defilement of persons living with disabilities attracts 14 years in prison, while obtaining persons for defilement, or employing threats or drugs, and false pretences and misrepresentation are misdemeanours. ${ }^{123}$

Furthermore, abduction or an attempt to abduct a woman under the age of 21 years for sexual purposes and prostitution will attract seven years in jail. ${ }^{124}$ The Penal Code also applies punitive measures to any homeowner who authorises the defilement of a girl under the age of 18. The penalty, in this case, is five years' imprisonment. ${ }^{125}$ Anyone who detains a woman or girl for sexual intent is liable to seven years' imprisonment, while the sexual exploitation of persons in detention by those in authority or other persons attracts capital punishment. ${ }^{126}$ Any conspiracy to defile a woman or girl is punishable with seven years in jail. ${ }^{127}$ Similarly, the Prevention of Trafficking in Persons Act bans the introduction or matchmaking of a person to a

\footnotetext{
116 Section 4(1)(6) of the Anti-Trafficking in Persons Act 6 of 2008.

$117 \quad$ Ntambala $v$ Uganda 2018 UGSC 1 (18 January 2018) para 2.

118 The sexual-offences aspect of the Act is currently under review by way of the Sexual Offences Bill (2016) as at 15 March 2019. Note that the Bill had passed its first reading. See Parliament Watch 2019 http://parliamentwatch.ug/bills/the-sexualoffenses-bill-2016/\#.XluoWCgzY2w; Ch X1V of the Penal Code Act, 1950 (Cap 120). Section 125 of the Penal Code Act, 1950 (Cap 120).

Section 126 of the Penal Code Act, 1950 (Cap 120).

Section 128 of the Penal Code Act, 1950 (Cap 120).

Section 129 of the Penal Code Act, 1950 (Cap 120).

Sections 130 and 132(1) of the Penal Code Act, 1950 (Cap 120).

Section 131 of the Penal Code Act, 1950 (Cap 120).

Section 133 of the Penal Code Act, 1950 (Cap 120).

Section 134 of the Penal Code Act, 1950 (Cap 120).

Section 140 of the Penal Code Act, 1950 (Cap 120).
} 
foreigner for marriage, ${ }^{128}$ recruitment, transportation, harbouring and reception of an individual for sexual exploitation and sex tourism. ${ }^{129}$ Persons convicted of these acts may be subject to a jail term ranging from 5-15 years, with or without the option of a fine. ${ }^{130}$

The analysis of the laws above shows that South Africa, Tanzania and Uganda have legislation combating sexual violence in their territories. Nevertheless, do refugees enjoy the protection of such laws? The article now attempts to establish whether cases of sexual violence get to the courts in these territories and whether cases of the same violence affecting refugees receive the same treatment.

\section{Access to courts in the contracting states}

Section 4 of this article analysed the law and procedures for dealing with sexual violence in South Africa, Tanzania and Uganda. However, this section will analyse documented decided cases of sexual violence in these countries of study, and ascertain whether they involve both their citizens and refugees.

\subsection{Data analysis}

Data were collected from documented decided court cases accessible online. In South Africa and Uganda, the data collected pertained ot the period 2013 and 2017, while the available data for Tanzania pertained to the period 2009 to 2016. Therefore, the figures here are a mere representation of the treatment of cases of sexual violence in these countries.

\subsection{Findings}

The data also revealed that both sexes suffered sexual violence. South Africa recorded five incidents involving male victims ${ }^{131}$ while the rest involved female victims, while Tanzania recorded one, ${ }^{132}$ and there was no record of male cases in Uganda.

\footnotetext{
128 Sections 8(e) of the Prevention of Trafficking in Persons Act 7 of 2009.

129 Sections 3(1)(a) and (b) of the Prevention of Trafficking in Persons Act 7 of 2009.

130 Sections 3(1) and 8 of the Prevention of Trafficking in Persons Act 7 of 2009.

131 S v Wamo 2013 JDR 0804 (GNP); S v Maseko 2013 JDR 0986 (GNP); S v Coetzee 2015 JDR 1979 (NCK); S v Mendile 2016 JDR 2010 (ECG); S v Gcaza 2017 JDR 0995 (SCA); S v AR 2017 JDR 1219 (WCC) 
The perpetrators of sexual violence in all three countries, as round in this study, were fathers, mothers (aiding and abetting), foster fathers, adopted fathers, pastors, grandfathers, stepfathers, brothers, spouses and uncles. ${ }^{133}$ Other relatives were former spouses and boyfriends, customary spouses and mothers' boyfriends. Acquaintences included neighbours, visitors to families, and friends of the family. ${ }^{134}$ Strangers included robbers, kidnappers, street people, persons in positions of trust such as clergymen, doctors, sports coaches, teachers, prophets, church members and taxi drivers, amongst others. ${ }^{135}$

\begin{tabular}{|l|l|l|}
\hline Country & Ages of victims & Ages of offenders \\
\hline South Africa & $2-85$ years $^{136}$ & $17-75$ years $^{137}$ \\
\hline Tanzania & $3-35$ years $^{138}$ & $18-45$ years $^{139}$ \\
\hline Uganda & $17-66$ years $^{140}$ & $2-75$ years $^{141}$ \\
\hline
\end{tabular}

Table 1: Age distribution of victims and perpetrators ${ }^{142}$

Table1 demonstrates the different ages of the victims and perpetrators of the act of sexual violence in the three countries. It attests to the fact that both children and adults are victims of this crime.

In addition, the types of sexual violence committed against all victims in cases prosecuted in South Africa included rape, gang-rape, defilement, rape of under 16 years of age, rape and murder, the exposure of children to pornography, Indecent assault, consensual penetration with a child, being an accomplice to an assailant in an act of rape, grievous bodily harm, sexual offences, sexual assault, and the grooming of children. ${ }^{143}$ There were also cases of assault grievous physical harm, rape with the mother as an accessory, anal and oral indecent assault, and the attempted rape of a boy. ${ }^{144}$ There were also cases of masturbation of the self and the victim,

$\begin{array}{ll}133 & \text { See the Appendix; Eberechi Access to Justice 222-225, 237-238, 250-252. } \\ 134 & \text { See the Appendix; Eberechi Access to Justice 222-225, 237-238, 250-252. } \\ 135 & \text { See Appendix; Eberechi Access to Justice 222-225, 237-238, 250-252. } \\ 136 & \text { Note that the exact ages of the victims were omitted from the judgement. } \\ 137 & \text { Note that the exact ages of the offenders were omitted from the judgement. } \\ 138 & \text { Note that the exact ages of the victims were omitted from the judgement. } \\ 139 & \text { Note that the exact ages of the offenders were omitted from the judgement. } \\ 140 & \text { Note that the exact ages of the victims were omitted from the judgement. } \\ 141 & \text { Note that the exact ages of the offenders were omitted from the judgement. } \\ 142 & \text { See the Appendix; Eberechi Access to Justice 222-225, 237-238, 250-252. } \\ 143 & \text { See the Appendix for a list of the cases; Eberechi Access to Justice 222-225. } \\ 144 & \text { See the Appendix for a list of the cases; Eberechi Access to Justice 222-225. }\end{array}$ 
compelling the victim to witness this and sexual assault, including hitting the victim on the mouth, throttling, grabbing a breast, pulling down the skirt, sexual assault, and forcefully touching the breasts and vagina. ${ }^{145}$ The species of sexual violence cases in Tanzania are unnatural offences and rape, attempted rape, and the sexual assault of a woman, ${ }^{146}$ and Uganda witnessed cases of rape, aggravated rape, aggravated defilement and simple defilement, amongst others. ${ }^{147}$

\begin{tabular}{|c|c|c|c|c|c|}
\hline Country & $\begin{array}{l}\text { Years } \\
\text { of } \\
\text { study }\end{array}$ & $\begin{array}{l}\text { Total } \\
\text { number of } \\
\text { decided } \\
\text { cases }\end{array}$ & $\begin{array}{l}\text { Citizens } \\
\text { who are } \\
\text { victims }\end{array}$ & Refugees & $\begin{array}{l}\text { Other } \\
\text { nationals }\end{array}$ \\
\hline $\begin{array}{l}\text { South } \\
\text { Africa }\end{array}$ & $\begin{array}{l}2013 \\
-2017\end{array}$ & 328 & 326 & None & $\begin{array}{l}\text { One victim } \\
\text { US citizen } \\
\text { One } \\
\text { Mozambican } \\
\text { offender }\end{array}$ \\
\hline Tanzania & $\begin{array}{l}2009- \\
2016\end{array}$ & 50 & 50 & None & None \\
\hline Uganda & $\begin{array}{l}2013- \\
2017\end{array}$ & 187 & 187 & None & None \\
\hline
\end{tabular}

Table 2: Prosecuted instances of sexual offences in the countries under study (see the Appendix for a list of the cases)

As shown in table 2, the inquiry into the prosecuted cases of sexual violence in South Africa ${ }^{148}$ shows that, between 2013 and 2017, 326 of 328 documented prosecuted decided occurrences of sexual offences concerned citizens and that, of the remaining two, one victim was a citizen of the United States of America and the other a Mozambican who was trafficking young girls for sexual purposes. No documented case pertains to a refugee. ${ }^{149}$

\footnotetext{
145 See the Appendix for a list of the cases; Eberechi Access to Justice 222-225.

146 See the Appendix for a list of the cases; Eberechi Access to Justice 237-238.

147 See the Appendix for a list of the cases; Eberechi Access to Justice 250-252.

148 Note that the figures in this subsection may not be comprehensive. The data were harvested from information that was accessible to the author in all three countries from decided court cases. See the Appendix below; Eberechi Access to Justice 222225, 237-238, 250-252.
}

149 Eberechi Access to Justice 226; S v De Wee 2017 JDR 0005 (ECG) 8; S v Dos Santos 2017 JDR 2053 (GP). 
While the study in Tanzania could not cover an equivalent period of five years in succession, ${ }^{150}$ the data revealed the documentation of more than 50 cases of sexual violence between 2009 and 2016. All of the cases invloved citizens, with there being no record of one involving a refugee. ${ }^{151}$ As for Uganda, the investigation found that in 2013 and 2017 there were 187 documented prosecuted cases of sexual violence. However, all cases involved citizens, and none concerned refugees. ${ }^{152}$

Based on Table 2, therefore, the author argues that refugees in South Africa and Uganda who are victims of sexual violence do not experience the prosecution of their assailants, while there are prosecuted cases that concerned other residents. In the case of Tanzania, it is not possible to draw any firm conclusions because of the poor documentation of the lack of documentation.

\section{Refugees and access to courts in contracting states}

To access basic amenities in South Africa, you need a passport, a permit or a South African identity document. Refugees in South Africa require an asylum permit to access facilities. The South African Urban Refugee Policy is applauded for its progressive nature, because it does not confine refugees to camps. ${ }^{153}$

Nevertheless, refugees' living conditions have been described as very poor, ${ }^{154}$ which defeats the objective of the liberal policy of integration. Some asylum seekers still have difficulty in either renewing or obtaining asylum permits due to the closure of some reception centres. ${ }^{155}$

In regard to access to courts, there are few documented cases relating to asylum status. ${ }^{156}$ Police personnel discriminate against and do not trust the

\footnotetext{
150 This was due to a lack of access to documentation.

151 Eberechi Access to Justice 250-252.

152 Eberechi Access to Justice 237-238.

153 Zamfir 2017 https://www.europarl.europa.eu/RegData/etudes/BRIE/2017/608698/ EPRS_BRI(2017)608698_EN.pdf.

$154 \mathrm{HRW}^{-} 2009 \mathrm{https} / / /$ www.hrw.org/report/2009/12/07/no-healing-here/violencediscrimination-and-barriers-health-migrants-south-africa.

155 Scalabrini Centre, Cape Town v Minister of Home Affairs 20184 SA 125 (SCA) para 12; Chambers 2017 https://www.timeslive.co.za/news/south-africa/2017-09-29reopen-cape-town-refugee-centre-appeal-court-orders-home-affairs/; Washinyira 2017 https://www.groundup.org.za/article/home-affairs-ordered-re-open-cape-townrefugee-office/.

156 Mohammed $v$ President of the Republic of South Africa 20013 SA 893 (CC); Lawyers for Human Rights v Minister of Home Affairs 20044 SA 125 (CC).
} 
complaints received from refugees who are victims of sexual violence. ${ }^{157}$ Thus, documented prosecuted cases of sexual violence against refugees in South Africa are yet to become available. As shown in Table 2, of the 328 prosecuted cases of sexual violence between 2013 and 2017, one victim was a US citizen and one perpetrator a Mozambican perpetrator. Otherwise all the cases related to South African citizens, with no case involving a refugee. ${ }^{158}$

The report indicates that female refugees were easy targets for sexual violence during the xenophobic attacks in South Africa, because they had less recourse to the criminal justice system and less protection than South African women. ${ }^{159}$ Further, the report states that despite an increase in the provision of health, psychosocial and legal services by the state and civil society organisations, refugee women still experience problems of access to protection, justice and services following sexual violence. ${ }^{160}$ Some of these problems are due to a lack of proper management of the cases and "[an absence of a] formal or consistent approach to referral". Also, survivors are charged for or denied access to free medical services, including postexposure prophylaxis, and there is a lack of shelter that complies with minimum standards. ${ }^{161}$ Most female refugees who suffer sexual violence in South Africa do not report the incident for fear of deportation. ${ }^{162}$

Based on the above analysis, the author submits that those female refugees who are victims of sexual violence do not have the same access to the courts as their South African counterparts. ${ }^{163}$ As such, South Africa may not be fulfilling its obligation to refugees as per the provisions of Article 16 of

\footnotetext{
157 Kasaman 2017 http://solidaritysummit.gou.go.ug/content/sexual-and-gender-basedviolence-refugee-context.

158 Kasaman $2017 \mathrm{http}: / /$ solidaritysummit.gou.go.ug/content/sexual-and-gender-basedviolence-refugee-context.

159 POWA and ALN 2010 https://tbinternet.ohchr.org/Treaties/CEDAW/ Shared\%20Documents/ZAF/INT_CEDAW_NGO_ZAF_48_10364_E.pdf 12.

160 POWA and ALN $2010 \mathrm{https}: / /$ tbinternet.ohchr.org/Treaties/CEDAW/Shared\%20 Documents/ZAF/INT_CEDAW_NGO_ZAF_48_10364_E.pdf; CSVR 2014 https://www.csvr.org.za/index.php.

161 POWA and ALN 2010 https://tbinternet.ohchr.org/Treaties/CEDAW/Shared\%20 Documents/ZAF/INT_CEDAW_NGO_ZAF_48_10364_E.pdf; CSVR 2014 https://www.csvr.org.za/index.php.

162 POWA and ALN 2010 https://tbinternet.ohchr.org/Treaties/CEDAW/Shared\%20 Documents/ZAF/INT_CEDAW_NGO_ZAF_48_10364_E.pdf 12; HRW Prohibited Persons 83.

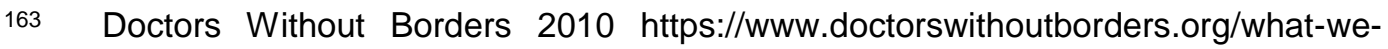
do/news-stories/research/ives-survival-migrants-and-refugees-south-africa Table 1,2 and 3.
} 
the 1951 Refugee Convention. The author recommends that these South Africa should extend the protection of these laws to refugees in its territory.

Turning to Tanzania, a study conducted in refugee camps by Women's Legal Aid of Tanzania in $2008^{164}$ found that despite the presence in camps of law enforcement officers and human rights NGOs, ${ }^{165}$ it remains problematic for refugee women and children to access the courts. Reports reveal that access to the services available in cases of sexual violence at the sexual and gender-based violence centre is limited to the deterring of exploitation, "awareness-raising, psychological and legal counselling". 166 Perpetrators are let free by the police; the courts sometimes disregard reported cases on grounds not understood by the victims; and some victims may not want to report violations to the authorities for fear of not been taken seriously or discounted. ${ }^{167}$

Discrimination against refugees and the deficiency of qualified staff accounts for the lack of the prosecution of cases. For instance, the district courts of Kibondo, which are responsible for the trial of cases of sexual violence from the Mtendeli, Kanembwa, Nduta and Mkugwa refugee camps, has two male police prosecutors, a male magistrate and a male interpreter with no training on how to handle cases of sexual violence. ${ }^{168} \mathrm{~A}$ lot of the prosecuted cases of such violence end in the acquittal of perpetrators because of shoddy investigation and inept prosecution.

In the Kibondo, Kasulu, Ngara and Kigoma refugee camps and districts courts one presiding magistrate complained of a lack of paper for the maintenance of the court record. ${ }^{169}$ The report also exposes the fact that it is difficult to attract qualified lawyers and prosecutors to those areas owing to their underdevelopment and inaccessibility, ${ }^{170}$ a difficulty which in turn limits access to the courts. Of about 50 decided cases of sexual violence studied during this research, there are no documented prosecuted cases of sexual violence against refugees in camps in Tanzania, as shown in Table 2 above. The author maintains that although there are few prosecuted cases of sexual violence against refugees in refugee camps in Tanzania, as reported by Human Rights Watch, ${ }^{171}$ the government of Tanzania needs to

\footnotetext{
164 WLAC Access to Justice viii.

165 WLAC Access to Justice vii.

166 WLAC Access to Justice 13

167 WLAC Access to Justice 14

168 Mabuwa Seeking Protection 60-61.

169 Mabuwa Seeking Protection 62.

170 Mabuwa Seeking Protection 62.

171 Mabuwa Seeking Protection 50.
} 
improve its compliance with the implementation of article 16 of the 1951 Refugee Convention.

Similarly, in a bid to facilitate court access for refugees in settlements, the government of Uganda, in collaboration with the UNHCR, established a mobile court to visit the Nakivale refugee settlement. ${ }^{172}$ Despite this initiative, court access for refugees remains a challenge for all refugees in the settlements in terms of the long distances complainants have to travel and the over-stretched national judiciary. ${ }^{173}$ At any rate, the mobile court serves only the Nakivale refugee settlement. ${ }^{174}$

However, prosecuted cases of sexual violence by the mobile courts in Uganda's refugee settlements are yet to be reported. ${ }^{175}$ Of about 187 prosecuted cases of sexual offences reviewed between 2013 and 2017 in Uganda, none involved refugee victims of sexual violence. ${ }^{176}$ Thus, the article submits that while the Ugandan government is taking steps to extend the prosecution of sexual violence to refugees in the various settlements, these efforts are yet to yield the desired result. The author therefore argues that Uganda has not fully complied with the provisions of Article 16 of the 1951 Refugee Convention.

\section{Conclusion}

Access to courts is a challenge for refugees who are victims of sexual violence in that they are typically uninformed about or unaware of the legal recourse and support available to them. ${ }^{177}$ The police presence in settlements is scant, with no means of effecting arrest on the assailants, and no transport and holding cells < Consequently, victims are reluctant to report violations and instead seek recourse through traditional dispute resolution, which usually leads, however, to re-victimisation. ${ }^{178}$ Other barriers to accessing courts include the cost of accessing government services and the scarcity of police medical examination forms for the examination of victims and offenders for the court trial. ${ }^{179}$ Police also lack a working knowledge of the resources available for addressing sexual

\footnotetext{
172 UNHCR Uganda 2014 https://data2.unhcr.org/es/documents/download/48494; Powell 2013 http://learningenglish.voanews.com/a/south-africa-rape-ugandarefugee-camp-drc-unhcr/1794666.html.

173 UNHCR Uganda 2014 https://data2.unhcr.org/es/documents/download/48494.

174 UNHCR Uganda 2014 https://data2.unhcr.org/es/documents/download/48494.

175 UNHCR Uganda 2014 https://data2.unhcr.org/es/documents/download/48494.

176 Eberechi Access to Justice 250-252.

177 UNHCR $2018 \mathrm{https}: / /$ data2.unhcr.org/en/documents/download/67864.

178 UNHCR 2018 https://data2.unhcr.org/en/documents/download/66524 6.

179 UNHCR 2018 https://data2.unhcr.org/en/documents/download/66524 6.
} 
violence, which contributes to victims' ignorance of the procedures to follow in accessing courts. ${ }^{180}$

This article reveals that South Africa, Tanzania and Uganda of a necessity facilitate access to courts for refugees who are victims of sexual violence in their territories since they have ratified and domesticated the 1951 Refugee Convention and its Protocol of 1967. Therefore they are bound under the treaty to protect and enforce the rights of refugees.

Regarding access to court, the three countries provide their citizens with such access, and all prohibit sexual violence, imposing penalties ranging from years of imprisonment to life and death sentences. In Tanzania and Uganda an additional punishment is corporal punishment, as determined by the court. The jurisdiction for addressing sexual violence in South Africa and Tanzania is Magistrate Courts; in Uganda, it is the High Court. The procedures for reporting the crime to the police are similar. South Africa has its Thuthuzela Care Centres, which are close to a one-stop facility located in hospitals and close to a police station, where victims of rape report and have access to facilities. In Tanzania, South Africa and Uganda, the victim is the complainant and principal witness, and the state prosecutes cases.

With regard to the treatment of refugees, there are as yet no documented prosecuted cases of sexual violence against refugees in South Africa. Tanzania reports prosecuting a few instances of sexual violence against refugees, but records are hard to find owing to poor documentation. ${ }^{181}$ Uganda has a mobile court dedicated to addressing the problem of sexual violence against refugees in settlements, but they are yet to record the prosecution of such cases. ${ }^{182}$

The author argues, therefore, that the contracting states should protect refugees against sexual violence, create a conducive environment for the reporting of such cases, and ensure that they hold perpetrators to account for such crimes so that the victims can have access to a court to testify against their assailants. Also, the author suggests that a one-stop model facility should be included in refugee camps/settlements design as recommended by Eberechi. ${ }^{183}$ The article recommends that states in breach of the article should be encouraged to comply with their obligations. ${ }^{184}$

\footnotetext{
180 UNHCR 2018 https://data2.unhcr.org/en/documents/download/66524 6.

181 Mabuwa Seeking Protection 62.

182 UNHCR Uganda 2014 https://data2.unhcr.org/es/documents/download/48494.

183 Eberechi Access to Justice 383-387.

184 Eberechi Access to Justice 312.
} 


\section{Bibliography}

\section{Literature}

Eberechi Access to Justice

Eberechi OE Access to Justice for Victims of Sexual Violence in Refugee Camps (LLD-dissertation University of Pretoria 2017)

Ferreira and Ferreira-Snyman 2014 PELJ

Ferreira $G$ and Ferreira-Snyman A "The Incorporation of Public International Law into Municipal Law and Regional Law against the Background of the Dichotomy between Monism and Dualism" 2014 PELJ 1471-1496

HRW Prohibited Persons

Human Right Watch Prohibited Persons: Abuse of Undocumented Migrants, Asylum Seekers and Refugees in South Africa (Human Right Watch New York 1998)

Jennings and Watts Oppenheim's International Law Jennings R and Watts A (eds) Oppenheim's International Law - Vol $19^{\text {th }}$ (Longman London 1993)

\section{Mabuwa Seeking Protection}

Mabuwa R Seeking Protection: Addressing Sexual and Domestic Violence in Tanzania's Refugee Camps (Human Right Watch New York 2000)

Obodoruku Human Information Behavior

Obodoruku B Human Information Behavior among African Refugees in Tanzania: An Exploratory Study of the Nyarugusu Camp (PhD-dissertation Long Island University 2014)

Obodoruku "Multiculturalism of Tanzanian Refugees"

Obodoruku B "Multiculturalism of Tanzanian Refugees in the Information Society and the United Nations High Commissioner for Refugees" Unpublished contribution delivered at the IFLA Satellite Meeting From Refugee to Citizen - Integration: Policies and Actions of Cultural Institutions (16-17 August 2017 Berlin)

Ramji-Nogales 2011 Int CLR

Ramji-Nogales $J$ "Questioning Hierarchies of Harm: Women Forced Migration and International Criminal Law" 2011 Int CLR 820-821 
Rathjen and Spaeth 1979 Am J Pol Sci

Rathjen GJ and Spaeth HJ "Access to the Federal Courts: An Analysis of Burger Court Policy Making" 1979 Am J Pol Sci 360-382

WLAC Access to Justice

Women's Legal Aid Centre Access to Justice for Refugee Women and Girls

- Baseline Survey Report Conducted in Mtabila, Nyarugusu, and Lugufu Camps (Women's Legal Aid Centre Dar-es-Salaam 2008)

\section{Case law}

Concorp International Ltd vs East and Southern Development Bank 2010 UGSC 19 (18 October 2010)

Glenister v President of the Republic of South Africa 20113 SA 347 (CC) Lawyers for Human Rights v Minister of Home Affairs 20044 SA 125 (CC) Levenstein $v$ Estate of the Late Sidney Lewis Frankel 2018 ZACC 16 (14 June 2018)

Mandela $v$ Minister of Prisons 19831 SA 938 (A)

Mohammed v President of the Republic of South Africa 20013 SA 893 (CC) Moses Muhagama Laurance v The Government of Zanzibar 2003 TZCA 3 (31 October 2003)

Ntambala v Uganda 2018 UGSC 1 (18 January 2018)

$S v A R 2017$ JDR 1219 (WCC)

S v Coetzee 2015 JDR 1979 (NCK)

S v De Wee 2017 JDR 0005 (ECG)

S v Dos Santos 2017 JDR 2053 (GP)

S v Gcaza 2017 JDR 0995 (SCA)

S v Makwanyane 19953 SA 391 (CC)

S v Maseko 2013 JDR 0986 (GNP)

S v Mendile 2016 JDR 2010 (ECG) 
S v Wamo 2013 JDR 0804 (GNP)

Scalabrini Centre, Cape Town v Minister of Home Affairs 20184 SA 125 (SCA)

Waziri Saldi v The Republic Criminal Appeal Case No 39 of 2012 (30 April 2015)

Wethered v Calcutt (1842) 4 Man \& G 566

\section{Legislation}

\section{South Africa}

Constitution of the Republic of South Africa, 1996

Criminal Law Amendment Act 105 of 1997

Criminal Law (Sexual Offences and Related Matters) Amendment Act 32 of 2007

Criminal Law (Sexual Offences and Related Matters) Amendment Act Amendment Act 5 of 2015

Criminal Procedure Act 51 of 1977

Legal Aid South Africa Act 39 of 2014

Prevention and Combating of Trafficking in Persons Act 7 of 2013

Refugees Amendment Act 11 of 2017

\section{Tanzania}

Anti-Trafficking in Persons Act 6 of 2008

Constitution of the United Republic of Tanzania, 1977

Criminal Procedure Act, 1985 (Cap 20)

Legal Aid Act 1 of 2017

National Prosecutions Service Act 27 of 2008

Penal Code of the Republic of Tanzania, 1945 (Cap 16) 
Refugee Act 9 of 1998

\section{Uganda}

Advocates (Legal Aid to Indigent Persons) Regulations, 2007

Constitution of the Republic of Uganda, 1995

Penal Code Act, 1950 (Cap 120)

Prevention of Trafficking in Persons Act 7 of 2009

Ratification of Treaties Act, 1998 (Cap 204)

Refugee Act 21 of 2006

Sexual Offences Bill (2016)

International instruments

Convention Relating to the Status of Refugees (1951)

Protocol Relating to the Status of Refugees (1967)

Vienna Convention on the Law of Treaties (1969)

\section{Government publications}

Gen N 862 in GG 39131 of 28 August 2015

\section{Internet sources}

Chambers 2017 https://www.timeslive.co.za/news/south-africa/2017-0929-reopen-cape-town-refugee-centre-appeal-court-orders-home-affairs/ accessed

Chambers D 2017 Reopen Cape Town Refugee Centre, Appeal Court Orders Home Affairs https://www.timeslive.co.za/news/south-africa/201709-29-reopen-cape-town-refugee-centre-appeal-court-orders-home-affairs/ accessed 11 April 2019

CSVR 2014 https://www.csvr.org.za/index.php Centre for the Study of Violence and Reconciliation 2014 Home Page https://www.csvr.org.za/index.php accessed 11 April 2019 
Dawa 2019 https://www.accord.org.za/conflict-trends/conflict-dynamics-inthe-bidibidi-refugee-settlement-in-uganda/

Dawa I 2019 Conflict Dynamics in the Bidibidi Refugee Settlement in Uganda https://www.accord.org.za/conflict-trends/conflict-dynamics-in-thebidibidi-refugee-settlement-in-uganda/ accessed 25 February 2020

Doctors Without Borders 2010 https://www.doctorswithout borders.org/what-we-do/news-stories/research/lives-survival-migrantsand-refugees-south-africa

Doctors Without Borders 2010 The Lives of Survival Migrants and Refugees in South Africa https://www.doctorswithoutborders.org/what-we-do/newsstories/research/ives-survival-migrants-and-refugees-south-africa accessed 11 April 2019

HRW $2009 \quad$ https://www.hrw.org/report/2009/12/07/no-healinghere/violence-discrimination-and-barriers-health-migrants-south-africa Human Rights Watch 2009 No Healing Here: Violence, Discrimination and Barriers to Health for Migrants in South Africa https://www.hrw.org/report/2009/12/07/no-healing-here/violencediscrimination-and-barriers-health-migrants-south-africa accessed 31 October 2017

FIDH 2008 https://www.fidh.org/IMG/pdf/za486a.pdf International Federation for Human Rights FIDH 2008 Surplus People? Undocumented and Other Vulnerable Migrants in South Africa https://www.fidh.org/IMG/pdf/za486a.pdf accessed 8 March 2019

Kasaman 2017 http://solidaritysummit.gou.go.ug/content/sexual-andgender-based-violence-refugee-context

Kasaman I 2017 Sexual and Gender-based Violence in the Refugee Context - Uganda Solidarity Summit on Refugees http://solidaritysummit. gou.go.ug//content/sexual-and-gender-based-violence-refugee-context accessed 28 March 2018

NPA 2009 https://www.npa.gov.za/sites/default/files/resources/public awareness/TCC_brochure_august_2009.pdf

National Prosecuting Authority 2009 Thuthuzela Care Centres (TCCs): Turning Victims into Survivors https://www.npa.gov.za/sites/default/files/ resources/public_awareness/TCC_brochure_august_2009.pdf accessed 10 April 2019 
Obitre-Gama 2000 https://www.who.int/tobacco/media/en/JUDY2000X.pdf Obitre-Gama J 2000 The Application of International Law into National Law, Policy and Practice https://www.who.int/tobacco/media/en/JUDY2000X.pdf accessed 16 February 2019

Parliament Watch 2019 http://parliamentwatch.ug/bills/the-sexual-offensesbill-2016/\#.XluoWCgzY2w

Parliament Watch 2019 The Sexual Offences Bill, 2016: First Reading http://parliamentwatch.ug/bills/the-sexual-offenses-bill-

2016/\#.XluoWCgzY2w accessed 15 March 2019

POWA and ALN 2010 https://tbinternet.ohchr.org/Treaties/CEDAW/ Shared\%20Documents/ZAF/INT_CEDAW_NGO_ZAF_48_10364_E.pdf People Opposing Women Abuse (POWA) with the AIDS Legal Network (ALN) 2010 Criminal Injustice: Violence Against Women in South Africa https:/ttbinternet.ohchr.org/Treaties/CEDAW/Shared\%20Documents/ZAF/I NT_CEDAW_NGO_ZAF_48_10364_E.pdf accessed 30 November 2016

Powell 2013 http://learningenglish.voanews.com/a/south-africa-rapeuganda-refugee-camp-drc-unhcr/1794666.html

Powell A 2013 Activists: Rape in Africa Driven by Inequality and Weak Prosecution http://learningenglish.voanews.com/a/south-africa-rapeuganda-refugee-camp-drc-unhcr/1794666.html accessed 11 April 2019

The New Arab 2016 https://www.alaraby.co.uk/english/society/2016/1/18/ europe-female-migrants-refugees-face-violence-and-sexual-harassment The New Arab 2016 Europe: Female Migrants, Refugees Face Violence and Sexual Harassment https://www.alaraby.co.uk/english/society/2016/ 1/18/europe-female-migrants-refugees-face-violence-and-sexualharassment accessed 10 April 2018

UNHCR 1991 https://www.unhcr.org/publications/legal/3d4f915e4/ guidelines-protection-refugee-women.html

Office of the United Nations High Commissioner for Refugees 1991 Guidelines on the Protection of Refugee Women https://www.unhcr.org/publications/legal/3d4f915e4/guidelines-protectionrefugee-women.html accessed 11 April 2019

UNHCR 1995 https://www.refworld.org/docid/3ae6b33e0.html

Office of the United Nations High Commissioner for Refugees 1995 Sexual Violence against Refugees: Guidelines on Prevention and Response https://www.refworld.org/docid/3ae6b33e0.html accessed 4 March 2020 
UNHCR 2003 https://www.unicef.org/emerg/files/gl_sgbv03.pdf

Office of the United Nations High Commissioner for Refugees 2003 Sexual and Gender-based Violence against Refugees, Returnees and Internally Displaced: Guidelines for Prevention and Response Persons https://www.unicef.org/emerg/files/gl_sgbv03.pdf accessed 11 March 2019

UNHCR 2016 https://data2.unhcr.org/en/documents/download/52601

Office of the United Nations High Commissioner for Refugees 2016 Factsheet: Sexual and Gender-Based Violence (SGBV) Situation in Nyarugusu, Nduta and Mtendeli Refugee Camps https://data2.unhcr.org/en/documents/download/52601 accessed 27 February 2019

UNHCR 2016 https://www.unhcr.org/protect/PROTECTION/3b73b0d63.pdf Office of the United Nations High Commissioner for Refugees 2016 States Parties to the 1951 Convention Relating to the Status of Refugees and the 1967 Protocol https://www.unhcr.org/protect/PROTECTION/3b73b0d63 .pdf accessed 9 April 2019

UNHCR 2018 https://data2.unhcr.org/en/documents/download/66524

Office of the United Nations High Commissioner for Refugees 2018 UNHCR Monthly Protection Update: Sexual and Gender-Based Violence (SGBV) September 2018 https://data2.unhcr.org/en/documents/download/66524 accessed 9 April 2019

UNHCR 2018 https://data2.unhcr.org/en/documents/download/67864

Office of the United Nations High Commissioner for Refugees 2018 UNHCR Monthly Protection Update: Sexual and Gender-based Violence (SGBV) December 2018 https://data2.unhcr.org/en/documents/download/67864 accessed 25 February 2019

UNHCR 2018 https://www.unhcr.org/afr/statistics/unhcrstats/5c52ea084/ mid-year-trends-2018.html

Office of the United Nations High Commissioner for Refugees 2018 MidYear Trends =https://www.unhcr.org/afr/statistics/unhcrstats/5c52ea084/ mid-year-trends-2018.html accessed 1 March 2019

UNHCR 2019 https://data2.unhcr.org/en/country/uga Office of the United Nations High Commissioner for Refugees 2019 Uganda Operational Portal: Refugee Situations https://data2.unhcr.org/en/country/ uga accessed 14 January 2019 
UNHCR Uganda 2014 https://data2.unhcr.org/es/documents/ download/48494

Office of the United Nations High Commissioner for Refugees Uganda 2014 SGBV Fact Sheet / Southwest Uganda / 2014 https://data2.unhcr.org/es/documents/download/48494 accessed 25 February 2019

UNICEF 2018 https://www.unicef.org/appeals/files/UNICEF_Tanzania_ Humanitarian_Situation_Report_August_2018.pdf

United Nations Children's Fund 2018 Tanzania Humanitarian Situation Report

https://www.unicef.org/appeals/files/UNICEF_Tanzania_Humanitarian_Sit uation_Report_August_2018.pdf accessed 26 February 2019

Vigaud-Walsh 2015 https://static1.squarespace.com/static/506c8ea1e 4b01d9450dd53f5/t/5678aee07086d7cddecf1bab/1450749707001/201512 22+Tanzania.pdf

Vigaud-Walsh F 2015 Women and Girls Failed: The Burundi Refugee Response in Tanzania https://static1.squarespace.com/static/506c8ea1e4 b01d9450dd53f5/t/5678aee07086d7cddecf1 bab/1450749707001/2015122 2+Tanzania.pdf accessed 11 March 2019

Washinyira 2017 https://www.groundup.org.za/article/home-affairsordered-re-open-cape-town-refugee-office/

Washinyira T 2017 Home Affairs Ordered to Re-open Cape Town Refugee Office: Supreme Court of Appeal Gives Department of Home Affairs until March 2018 https://www.groundup.org.za/article/home-affairs-ordered-reopen-cape-town-refugee-office/ accessed 11 April 2019

Zamfir $2017 \quad$ https://www.europarl.europa.eu/RegData/etudes/ BRIE/2017/608698/EPRS_BRI(2017)608698_EN.pdf

Zamfir L 2017 Refugee Policies in Africa: Open Borders but Limited Integration

https://www.europarl.europa.eu/RegData/etudes/BRIE/2017/608698/EPR

S_BRI(2017)608698_EN.pdf accessed 6 March 2020

\section{List of Abbreviations}

AIDS

ALN

Am J Pol Sci
Acquired Immunodeficiency Syndrome

AIDS Legal Network

American Journal of Political Science 
CSVR

FIDH

HIV

HRW

Int CLR

LGBT

NGO

NPA

PELJ

POWA

PTSD

SOCA

STD

STI

UN

UNCHR

UNICEF

WLAC
Centre for the Study of Violence and Reconciliation

International Federation for Human Rights

Human Immunodeficiency Virus

Human Rights Watch

International Criminal Law Review

lesbian, gay, bisexual and transgender

non-governmental organisation

National Prosecuting Authority

Potchefstroom Electronic Law Journal

People Opposing Women Abuse

Post-traumatic stress disorder

Sexual Offences and Community Affairs Unit

Sexually transmitted disease

Sexually transmitted infection

United Nations

Office of the United Nations High Commissioner for Refugees

United Nations Children's Fund

Women's Legal Aid Centre

\section{APPENDIX}

\section{South Africa}

Director of Public Prosecutions v Alberts 2016 JDR 1280 (GP)

MDT v S 2014 ZASCA 15 (20 March 2014)

Moganedisa v S 20141 SACR 53 (GNP)

Mulovhedzi v The State 2013 ZASCA 201 (2 December 2013)

Mudau v The State 2012 ZASCA 56 (9 May 2013)

S v Abraham 2013 JDR 0909 (ECG) 
S v Abisalile 2015 JDR 2391 (ECG)

S v AL 2016 JDR 0199 (ECG)

S v ALM 2013 JDR 1584 (FB)

$S$ v AR 2013 JDR 2186 (SCA)

$S$ v AR 2017 JDR 1219 (WCC)

S v Amerika 2017 JDR 0025 (WCC)

S v Baadjies 2017 JDR 1010 (WCC)

S v Bangala 2014 JDR 0919 (GSJ)

S v Bari 2015 JDR 1951 (ECG)

S v Bopape 2016 JDR 0652 (GJ)

S v Booysen 2013 JDR 0789 (GNP)

S v Calvin 2014 JDR 2020 (SCA)

S v Cebekhulu 2016 JDR 0649 (GJ)

S v Chake 2013 JDR 2184 (SCA)

S v Chauke 2014 JDR 0351 (GNP)

S v Chauke 2015 JDR 1522 (GP)

S v Chinridze 2014 JDR 1516 (GP)

S v Cock 2015 JDR 0155 (ECG)

$S$ v Coetzee 2015 JDR 1979 (NCK)

S v Cornelius 2013 JDR 0544 (ECG)

S v De Wee 2017 JDR 0005 (ECG) (victim is USA citizen)

S v Dire 2015 JDR 0660 (GP)

S v DL 2015 JDR 2681 (ECG)

S v Dladla 2015 JDR 0239 (GP) 
S v Dlamini 2015 JDR 0257 (KZP)

S v Dlangamandla 2017 JDR 0605 (GP)

S v Dos Santos 2017 JDR 2053 (GP)

S v Draghoender 2014 JDR 2108 (ECG)

S v Du Plessis 2016 JDR 1241 (GP)

S v Dube 2016 JDR 1760 (SCA)

S v Duma 2016 JDR 0232 (KZP)

S v Enslin 2017 JDR 0241 (GP)

S v Fakude 2017 JDR 0991 (GP)

S v FFD 2013 JDR 0007 (GNP)

S v Flietor 2013 JDR 0931 (FB)

$S$ v FM 2016 JDR 1564 (GP)

S v Fongoqa 2015 JDR 0947 (WCC)

S v Ganga 2015 JDR 2561 (WCC)

S v Gcaza 2016 JDR 1896 (ECG)

S v Gcaza 2017 JDR 0995 (SCA)

S v GO 2017 JDR 1582 (SCA)

S v Govender 2016 JDR 0265 (KZP)

S v Gqoba 2016 JDR 1454 (ECG)

S v Guamba 2014 JDR 2683 (FB)

S v Gubuza 2014 JDR 0625 (WCC)

S v Gwarubana 2015 JDR 1697 (WCC)

S v Gwedlane 2015 JDR 2623 (GP)

S v H 2014 JDR 1917 (GJ) 
S v Hargreaves 2015 JDR 0703 (KZP)

S v HCB 2014 JDR 1327 (GP)

S v Hewitt 2016 JDR 1079 (SCA)

S v Hekke 2014 JDR 2330 (ECG)

$S$ v JA 2017 JDR 0621 (NCK)

S v Jacobs 2014 JDR 2723 (WCC)

S v Jafta 2017 JDR 0411 (ECG)

$S$ v Jaftha 2015 JDR 2250 (ECG)

$S$ v JBN 2013 JDR 0206 (ECG)

S v Jezile (Seven Amici Curiae) 2015 JDR 0566 (WCC)

$S$ v Joe 2014 JDR 0803 (ECG)

S v Johannes 2014 JDR 2509 (WCC)

$S v$ JR and WN 2014 JDR 2515 (GP)

$S$ v Kaywood 2016 JDR 2203 (SCA)

S v Kekana 2014 JDR 0740 (GNP)

S v Khoza 2013 JDR 0395 (GNP)

S v Khumalo 2014 JDR 2681 (FB)

S v Khumalo 2017 JDR 0589 (GJ)

S v Klaas 2013 JDR 1370 (KZP)

S v Kleinhans 2014 JDR 0957 (WCC)

S v Kruger 2013 JDR 2713 (SCA)

S v Kwinda 2014 JDR 2013 (SCA)

S v Larry 2014 JDR 1291 (WCC)

S v Lebopa 2015 JDR 0836 (GP) 
S v Leve 2013 JDR 0110 (ECG)

S v LK 2013 JDR 1821 (GSJ)

S v Lokhotshwayo 2015 JDR 0496 (GP)

S v Lore 2015 JDR 0044 (GJ)

S v LP 2014 JDR 0231 (WCC)

S v Lunga 2014 JDR 1193 (GP)

S v Luruli 2013 JDR 2553 (GSJ)

S v Mabaso 2013 JDR 1425 (KZP)

S v Mabena 2014 JDR 0674 (GP)

S v Mabula 2013 JDR 1137 (GNP)

S v Mabuza 2016 JDR 0517 (GP)

S v Madiba 2014 JDR 0556 (SCA)

S v Madisha 2016 JDR 0049 (GP)

S v Maduna 2017 JDR 0398 (FB)

S v Madyo 2015 JDR 1103 (ECG)

S v Magano 2014 JDR 0720 (GNP)

S v Magazi 2016 JDR 1027 (FB)

S v Magezi 2013 JDR 2716 (SCA)

S v Mahinje 2014 JDR 2571 (ECB)

S v Mahlaba 2016 JDR 1594 (FB)

S v Mahlangu 2015 JDR 0179 (GP)

S v Mahlangu 2015 JDR 1606 (GP)

S v Mahlangu 2016 JDR 0095 (GP)

S v Mahlangu 2016 JDR 1562 (GP) 
S v Majola 2013 JDR 0400 (GNP)

S v Makamo 2015 JDR 0045 (GJ)

S v Makaringe 2016 JDR 1327 (NWM)

S v Makatu 2013 JDR 2422 (SCA)

S v Makgai 2013 JDR 1626 (GNP)

S v Makhakha 2013 JDR 1935 (WCC)

S v Makhalima 2016 JDR 0157 (GP)

S v Makhang 2017 JDR 0540 (ECG)

S v Makhendlana 2015 JDR 0788 (ECG)

S v Makoa 2014 JDR 2612 (GP)

$S$ v Makube 2015 JDR 1281 (GP)

$S$ v Malebe 2014 JDR 0311 (GNP)

S v Malakeje 2016 JDR 1103 (NWM)

S v Maleka 2015 JDR 0524 (GP)

$S$ v Malgas 2016 JDR 0909 (ECG)

S v Mali 2015 JDR 0662 (GP)

S v Manana 2014 JDR 0732 (GNP)

S v Manoni 2015 JDR 2682 (ECG)

S v Manzini 2016 JDR 0992 (ECG)

S v Mapipa 2016 JDR 1977 (ECG)

S v Marutla 2015 JDR 0557 (GP)

S v Maseko 2013 JDR 0986 (GNP)

S v Maseko 2016 JDR 1299 (GP)

S v Mashigo 2015 JDR 0907 (SCA) 
S v Masilo 2014 JDR 1916 (GP)

S v Masiteng 2016 JDR 0818 (GP)

S v Masuku 2013 JDR 1093 (GNP)

S v Maswanganyi 2013 JDR 2521 (GNP)

S v Mathuse 2013 JDR 2610 (GSJ)

S v Matthys 2015 JDR 1702 (WCC)

S v Mawasha 2016 JDR 1262 (GP)

S v Maxabaniso 2015 JDR 0843 (ECG)

S v Mayisela 2013 JDR 0752 (GNP)

S v Mazibuko 2014 JDR 0320 (GNP)

S v Mazondwa 2013 JDR 0715 (ECG)

S v MB 2016 JDR 2132 (WCC)

$S$ v Mbetha 2015 JDR 0497 (GP)

S v Mbokazi 2015 JDR 1611 (KZD)

S v Mcambi 2014 JDR 2268 (GP)

S v MD 2017 JDR 0624 (ECB)

S v MDT 2014 JDR 0586 (SCA)

S v Mdaka 2014 JDR 0953 (KZP)

S v Memane 2016 JDR 1255 (GP)

S v Mendile 2016 JDR 2010 (ECG)

S v MG 2015 JDR 0131 (GP)

S v Mgandela 2016 JDR 1748 (ECM)

S v Mgangala 2014 JDR 2442 (ECB)

S v Mgxeke 2013 JDR 2161 (ECG) 
S v Mhlahlo 2014 JDR 2438 (ECG)

S v Milisi 2016 JDR 2336 (ECG)

S v Mini 2015 JDR 2253 (ECG)

$S$ v MJM 2014 JDR 1525 (GP)

S v Mkhatshwa 2015 JDR 1104 (GP)

S v Mkhungo 2015 JDR 1687 (KZP)

S v Mkhwanazi 2016 JDR 0579 (GP)

S v ML 2014 JDR 0782 (GP)

S v Mlangeni 2015 JDR 2233 (GP)

S v Mletshe 2014 JDR 0388 (ECM)

S v Moabi 2015 JDR 1845 (GP)

S v Modiko 2015 JDR 1763 (GP)

$S$ v Modise 2014 JDR 2619 (FB)

S v Modise 2017 JDR 1125 (NWM)

S v Mofokeng 2014 JDR 1814 (FB)

S v Mofokeng 2016 JDR 0840 (FB)

S v Mofokeng 2016 JDR 1144 (GJ)

S v Mofokeng 2016 JDR 1591 (FB)

S v Mohalalelwa 2015 JDR 0526 (GP)

S v Moilwa 2017 JDR 1018 (GP)

S v Mokhari 2014 JDR 1370 (GJ)

S v Mokoena 2013 JDR 0635 (GNP)

S v Mokoena 2015 JDR 0554 (GP)

S v Molat/hehi 2015 JDR 0498 (GP) 
S v Molatudi 2015 JDR 2319 (GJ)

S v Molefe 2014 JDR 1317 (GP)

S v Molelekoa 2014 JDR 1115 (ECP)

S v Moloi 2013 JDR 0411 (FB)

S v Molokoane 2014 JDR 2067 (GP)

S v Moloto 2015 JDR 0486 (GP)

S v Moremi 2015 JDR 1323 (GP)

S v Mosethla 2014 JDR 1282 (GP)

$S$ v Moss 2015 JDR 0846 (ECG)

S v Mothata 2015 JDR 0527 (GP)

S v Motsamai 2016 JDR 2038 (FB)

S v Motshaba 2014 JDR 1711 (GP)

S v Motshabi 2017 JDR 0255 (GJ)

S v Motsoeneng 2016 JDR 1592 (FB)

S v Mouers 2016 JDR 1464 (NWM)

S v Mphaphuli 2014 JDR 0310 (GNP)

S v Mphephuka 2013 JDR 0766 (GNP)

S v Mpithi 2015 JDR 1330 (GP)

S v Mpofu 2014 JDR 0460 (GSJ)

S v Mqulwana 2014 JDR 2163 (ECG)

$S$ v Mroleli 2016 JDR 0006 (ECB)

S v MS 2013 JDR 1133 (GNP)

S v MS 2017 JDR 0295 (FB)

S v Msibi 2015 JDR 0193 (GP) 
S v Msibi 2016 JDR 1550 (KZP)

S v Msindwana 2013 JDR 0841 (ECG)

S v MT 2013 JDR 2102 (SCA)

S v Mthembu 2013 JDR 0703 (GNP)

S v Mthembu 2014 JDR 1561 (GP)

S v Mthimkulu 2016 JDR 0296 (GP)

S v Mthimunye 2015 JDR 0773 (GP)

S v Mthiyane 2015 JDR 1280 (GP)

$S$ v Mthombeni 2014 JDR 0706 (GNP)

S v Mthombeni 2014 JDR 2446 (KZP)

S v Mthombeni 2015 JDR 1524 (GP)

S v Mtyala 2015 JDR 0178 (GP)

S v Mudau 2013 JDR 0938 (SCA)

S v Mudzanani 2013 JDR 2747 (SCA)

S v Mugridge 2013 JDR 0658 (SCA)

S v Mugwedi 2014 JDR 0595 (SCA)

S v Munyai 2014 JDR 0604 (SCA)

S v Munyai 2015 JDR 0121 (GP)

S v N 2015 JDR 2300 (GP)

S v Ndaba 2014 JDR 0525 (GSJ)

S v Ndebele 2014 JDR 0376 (GSJ)

S v Ndimande 2015 JDR 1416 (KZD)

S v Ndlovu 2014 JDR 1151 (GP)

S v Ndubatha 2015 JDR 2303 (GP) 
S v Nduna 2013 JDR 0617 (GNP)

S v Nengudza 2015 JDR 2584 (GP)

S v Nevilimadi 2014 JDR 0662 (SCA)

S v Ngcobo 2014 JDR 0485 (KZP)

S v Ngcobo 2015 JDR 0923 (KZP)

S v Ngwane 2014 JDR 2699 (WCC)

S v Ngwase 2015 JDR 0559 (GP)

S v Ngwenya 2014 JDR 1620 (GP)

S v Nhleko 2016 JDR 1015 (GP)

S v Nkabinde 2014 JDR 2338 (FB)

S v Nkosi 2014 JDR 0676 (GNP)

S v Nkosi 2014 JDR 1076 (GP)

S v Nkuna 2017 JDR 1020 (GJ)

S v Nkunkuma 2013 JDR 2158 (SCA)

S v Nkwanyane 2014 JDR 2266 (KZP)

S v Nkwanyana 2016 JDR 1762 (KZP)

S v Nohaji 2016 JDR 0575 (ECM)

S v Nokeva 2013 JDR 0272 (ECG)

S v Nombiba 2014 JDR 1551 (GP)

S v Nombiba 2014 JDR 1554 (GP)

S v NS 2014 JDR 1344 (GP)

S v Ntepe 2016 JDR 1041 (FB)

S v Nthabalala 2014 JDR 0608 (SCA)

S v Ntozini 2015 JDR 1953 (ECG) 
S v Ntsasa 2014 JDR 1215 (FB)

S v Ntshabele 2016 JDR 0837 (GP)

S v Nxele 2014 JDR 0484 (KZP)

S v Nyaki 2014 JDR 0461 (GSJ)

S v Palmer 2017 JDR 1552 (SCA)

S v Pebane 2013 JDR 1125 (GNP)

S v Peyani 2013 JDR 2449 (GNP)

S v Phage 2016 JDR 1232 (GP)

S v Phaliso 2015 JDR 1289 (FB)

S v Phosha 2014 JDR 1535 (GP)

S v Pilane 2017 JDR 0103 (NWM)

S v PN 2014 JDR 0593 (SCA)

S v Polorie 2015 JDR 1093 (FB)

S v Poni 2016 JDR 1030 (ECG)

S v Poswa 2016 JDR 2332 (ECG)

S v Potgieter 2014 JDR 2222 (GP)

S v Prins 2016 JDR 1716 (WCC)

S v Pukane 2014 JDR 0458 (GSJ)

S v Qila 2014 JDR 2256 (ECG)

S v Qoka 2013 JDR 0992 (GNP)

S v Radebe 2016 JDR 1436 (GP)

S v Ragaval 2016 JDR 1398 (ECG)

S v Rakhudu 2016 JDR 1115 (GJ)

S v Ramonyathi 2014 JDR 2269 (GP) 
S v Ratseke 2013 JDR 2450 (GNP)

S v Ravele 2014 JDR 1903 (SCA)

S v RC 2015 JDR 1685 (KZP)

S v Rooiberg 2015 JDR 0740 (ECG)

S v Ruiters 2015 JDR 1966 (ECG)

S v Rumbu 2016 JDR 1117 (ECG)

S v Seedat 2015 JDR 0917 (GP)

S v Seedat 2016 JDR 1820 (SCA)

S v Sekamette 2016 JDR 1140 (GP)

S v Sekamette 2016 JDR 1259 (GP)

S v Selebogo 2015 JDR 1034 (GJ)

S v September 2014 JDR 1105 (ECG)

S v Setshedi 2017 JDR 0246 (GP)

S v Shiko 2014 JDR 1581 (GP)

S v Shongwe 2016 JDR 1141 (GP)

S v Silo 2016 JDR 0524 (WCC)

S v Sithole 2016 JDR 1260 (GP)

S v SLW 2014 JDR 1790 (ECP)

S v SM 2015 JDR 1185 (GP)

S v SMM 2013 JDR 1771 (GNP)

S v Solo 2015 JDR 1292 (FB)

S v Sovasi 2013 JDR 0781 (ECG)

S v Steyn 2014 JDR 2271 (GJ)

S v Strydom 2015 JDR 0484 (GP) 
S v SV 2015 JDR 1242 (GP)

S v Syster 2014 JDR 2544 (SCA)

S v T 2017 JDR 0862 (GP)

$S v$ Thafeni 2015 JDR 0750 (ECG)

S v Tshabalala 2013 JDR 1310 (GNP)

S v Tshabalala 2014 JDR 1178 (GP)

S v Tshabuse 2013 JDR 0990 (GNP)

S v Thulare 2013 JDR 2233 (GNP)

S v Thunzi 2014 JDR 0765 (WCC)

S v Tisani 2013 JDR 2163 (ECG)

S v Tivane 2015 JDR 0881 (GP)

S v Tladi 2015 JDR 0583 (GP)

$S v$ Tofa 2015 JDR 0570 (SCA)

S v Toli 2015 JDR 0765 (ECG)

S v Tose 2014 JDR 0857 (ECP)

S v Trosello 2015 JDR 2624 (GP)

S v Tshabalala 2014 JDR 1178 (GP)

S v Tshirana 2015 JDR 0039 (ECG)

S v Tshoga 2017 JDR 0057 (SCA)

S v Tuswa 2013 JDR 0226 (KZP)

S v Van Wyk 2014 JDR 2001 (SCA)

S v Voster 2013 JDR 0905 (GSJ)

S v Wamo 2013 JDR 0804 (GNP)

$S v$ WH 2016 JDR 1033 (FB) 
$S v$ Wonci 2015 JDR 0589 (ECG)

$S$ v Xaba 2013 JDR 0993 (GNP)

$S$ v ZF 2015 JDR 2411 (KZP)

S v Zondo 2015 JDR 0278 (KZP)

S v Zuba 2014 JDR 0155 (ECG)

S v Zulu 2015 JDR 1044 (GP)

$S$ v Zungula 2015 JDR 0556 (GP)

S v Zwane 2016 JDR 0875 (GJ)

Seedat v S 20152 SACR 612 (GP)

\section{Tanzania}

Abel Masikiti $v$ The Republic Criminal Appeal Case No 24 of 2015 (21 August 2015)

Abdullah Ally v The Republic Criminal Appeal Case No 253 of 2013 (10 and 21 July 2015)

Adam Rajabu v The Republic Criminal Appeal Case No 369 of 2014 (8 June 2015)

Ally Bakari Danga v The Republic Criminal Appeal Case No 103 of 2015 (13 August 2015)

Amiri Omary v The Republic Criminal Appeal Case No 6 of 2014 (19 August 2015)

David Hallnga $v$ The Republic Criminal Appeal Case No 12 of 2015 (19 \& 24 August 2015)

Emmanuel Adam v The Republic Criminal Appeal Case No 31 of 2015 (17 August 2015)

Faraja Leserian v The Republic Criminal Appeal Case No 93 of 2009 (18 November 2011) 
Haji Omary v The Republic Criminal Appeal Case No 307 of 2009 (29 September 2015)

Hamisi Shabani v The Republic Criminal Appeal Case No 227 of 2013 (30 April 2015)

Hassan Bundala@Swaga v The Republic Criminal Appeal Case No 386 of 2015 (18\& 23 February 2016)

Israel Abraham v The Republic Criminal Appeal Case No 97 of 2009 (22 November 2011)

Juma Magori @ Patrickv The Republic Criminal Appeal Case No 328 of 2014 (5 June 2015)

Jovitus Johansen v The Republic Criminal Appeal Case No 509 of 2015 (20 February 2016)

Kimbute Otiniel $v$ The Republic Criminal Appeal Case No 300 of 2011 (21 November 2014 and 25 April 2016)

Layford Makene $v$ The Republic Criminal Appeal Case No 45 of 2009 (29 June 2011)

Leiyani Meshikoki v The Republic Criminal Appeal Case No 31 of 2009 (8 November 2011)

Matano Mnama v The Republic Criminal Appeal Case No 361 of 2014 (2 June 2015)

Mathias Barua v The Republic Criminal Appeal Case No 105 of 2015 (13 August 2015)

Misago Ndendakumana $v$ The Republic Criminal Appeal Case No 540 of 2015 (9 February 2016)

Mohamed Ally v The Republic Criminal Appeal Case No 356A of 2014 (8 July 2015)

Mwanamaganga v R 2009 TZCA 6 (20 November 2009)

Nassibusio Abdallah $v$ The Republic Criminal Appeal Case No 39 of 2009 (6 September 2013) 
Niyonzimana Augustine $v$ The Republic Criminal Appeal Case No 483 of 2015 (20 February 2016)

Oroondi S/O Juma $v$ The Republic Criminal Appeal Case No 236 of 2012 (14 July 2015)

Petro Andrea $v$ The Republic Criminal Appeal Case No 108 of 2009 (28 November 2011)

Ramadhani Rashidi $v$ The Republic Criminal Appeal Case No 22 of 2008 (13 April 2015)

Ramadhani Sheklka $v$ The Republic Criminal Appeal Case No 330 of 2009 (30 July 2013)

Said Msusa v The Republic Criminal Appeal Case No 268 of 2013 (16 July 2015)

Saimon Mwajanga v The Republic Criminal Appeal Case No 19 of 2015 (19 August 2015)

Saning'o Meshuki Mollel v The Republic Criminal Appeal Case No 3 of 2009 (28 November 2011)

Shija Juma $v$ The Republic Criminal Appeal Case No 383 of 2015 (19 February 2016.)

Shija Shiloto $v$ The Republic Criminal Appeal Case No 162 of 2009 (1 July 2011)

Shila S/O Bosco@ Hamis v The Republic Criminal Appeal Case No 20B of 2009 (15 April 2015)

Sonda Sio Deus@ Mayombi v The Republic Criminal Appeal Case No 75 of 2009 (16 September 2013)

Tauta Kikoris v The Republic Criminal Appeal Case No 94 of 2009 (4 November 2011)

Waziri Saldi v The Republic Criminal Appeal Case No 39 of 2012 (30 April 2015)

Yust Lala v The Republic Criminal Appeal Case No 90 of 2015 (15 October 2015) 
Yustinian Mulokozi v The Republic Criminal Appeal Case No 7 of 2015 (15 February 2016)

\section{Uganda}

Abacha $v$ Uganda 2016 UGHCCRD 82 (26 July 2016)

Adriko v Uganda 2016 UGHCCRD 106 (28 November 2016)

Andama v Uganda 2016 UGHCCRD 105 (10 November 2016)

Awandal v Uganda 2016 UGHCCRD 11 (14 July 2016)

Bamanya v Uganda 2013 UGHCCRD 66 (23 October 2013)

Busiku v Uganda 2015 UGSC 3 (24 March 2015)

Kamanyiro v Uganda 2015 UGHCCRD 23 (31 July 2015)

Kasajja v Uganda 2015 UGHCCRD 30 (7 April 2015)

Komakech v Uganda 2014 UGHCCRD 82 (20 June 2014)

Lumala v Uganda 2016 UGHCCRD 138 (12 October 2016)

Lutalo v Uganda 2016 UGHCCRD 137 (25 October 2016)

Masaba v Uganda 2016 UGHCCRD 136 (12 October 2016)

Mubiru Ali v Uganda 2014 UGHCCRD 109 (30 May 2014)

Mubiru Kisingiri v Uganda 2016 UGHCCRD 6 (19 April 2016)

Musede v Uganda 2015 UGHCCRD 17 (17 April 2015)

Naluwemba v Uganda 2014 UGHCCRD 35 (19 July 2014)

Muwonge v Uganda 2016 UGHCCRD 116 (9 December 2016)

Ochima v Uganda 2016 UGHCCRD 12 (20 July 2016)

Ochima v Uganda 2016 UGHCCRD 78 (20 July 2016)

Rev Father Santos Wapokra v Uganda 2016 UGHCCRD 48 (7June 2016)

Uganda v Abdala Nabil 2016 UGHCCRD 69 (20 September 2016) 
Uganda v Aberninga 2017 UGHCCRD 69 (19 April 2017)

Uganda v Abiriga alias Mayia 2016 UGHCCRD 84 (30 August 2016)

Uganda v Acema 2016 UGHCCRD 81 (4 August 2016)

Uganda v Achia 2017 UGHCCRD 119 (28 September 2017)

Uganda v Adritia 2017 UGHCCRD 73 (19 April 2017)

Uganda v Agatiyo 2016 UGHCCRD 57 (23 August 2016)

Uganda v Akope 2017 UGHCCRD 122 (29 September 2017)

Uganda v Aleper 2014 UGHCCRD 62 (22 September 2014)

Uganda v Alepere 2017 UGHCCRD 123 (29 September 2017)

Uganda v Amidu 2017 UGHCCRD 106 (28 June 2017)

Uganda v Andabati 2016 UGHCCRD 87 (6 October 2016)

Uganda v Andama 2016 UGHCCRD 127 (8 December 2016)

Uganda v Angumaniyo 2017 UGHCCRD 102 (28 June 2017)

Uganda $v$ Anyolitho 2017 UGHCCRD 17 (2 February 2017)

Uganda v Arukor 2013 UGHCCRD 85 (1 November 2013)

Uganda v Atabua 2017 UGHCCRD 54 (19 April 2017)

Uganda v Atandu 2017 UGHCCRD 66 (19 April 2017)

Uganda v Atelemong 2017 UGHCCRD 84 (18 April 2017)

Uganda v Avaga 2017 UGHCCRD 63 (19 April 2017)

Uganda v Awekonimungu 2016 UGHCCRD 129 (23 December 2016)

Uganda v Ayebare 2017 UGHCCRD 114 (28 August 2017)

Uganda v Ayimani 2017 UGHCCRD 62 (19 April 2017)

Uganda v Ayungarach 2017 UGHCCRD 20 (10 July 2017)

Uganda v Bagira 2016 UGHCCRD 117 (13 October 2016) 
Uganda v Bahena 2016 UGHCCRD 118 (11 October 2016)

Uganda v Bainomugisha 2013 UGHCCRD 9 (26 March 2013)

Uganda v Balikamanya 2012 UGHCCRD 04 (9 January 2014)

Uganda v Baluku 2013 UGHCCRD 16 (22 April 2013)

Uganda v Balunywa 2011 UGHCCRD 46 (1 October 2013)

Uganda v Bamigwa 2014 UGHCCRD 95 (14 May 2014)

Uganda v Barisigala 2016 UGHCCRD 20 (19 May 2016)

Uganda v Burimwezi 2017 UGHCCRD 111 (30 May 2017)

Uganda v Byamukama 2016 UGHCCRD 94 (10 November 2016)

Uganda v Byarugaba 2017 UGHCCRD 116 (15 August 2017)

Uganda v Candia 2017 UGHCCRD 109 (15 June 2017)

Uganda v Chekuta 2017 UGHCCRD 125 (15 August 2017)

Uganda v Chelimo 2016 UGHCCRD 110 (21 September 2016)

Uganda v Dimba 2017 UGHCCRD 5 (16 January 2017)

Uganda v Dradriga 2016 UGHCCRD 76 (30 August 2016)

Uganda v Drasiku 2017 UGHCCRD 56 (19 April 2017)

Uganda v Ebau 2014 UGHCCRD 44 (2 April 2014)

Uganda v Eeru 2014 UGHCCRD 45 (14 March 2014)

Uganda v Eguru 2011 UGHCCRD 84 (19 December 2013)

Uganda v Ejoyi 2017 UGHCCRD 51 (19 April 2017)

Uganda v Emuteng 2013 UGHCCRD 88 (19 December 2013)

Uganda v Enyangu 2014 UGHCCRD 46 (18 June 2014)

Uganda v Epuku 2013 UGHCCRD 89 (1 November 2013)

Uganda v Erisa 2013 UGHCCRD 91 (30 October 2013) 
Uganda v Esia 2013 UGHCCRD 92 (24 October 2013)

Uganda v Etonu 2014 UGHCCRD 47 (18 June 2014)

Uganda v Gaijok 2015 UGHCCRD 16 (10 June 2015)

Uganda v Gimei 2014 UGHCCRD 13 (22 January 2014)

Uganda v Inuot 2014 UGHCCRD 48 (8 January 2014)

Uganda v Kahiriita 2016 UGHCCRD 119 (24 September 2016)

Uganda v Kahooza 2016 UGHCCRD 96 (10 November 2016)

Uganda v Kalani 2017 UGHCCRD 91 (26 February 2017)

Uganda v Kamugisha 2016 UGHCCRD 25 (28 April 2016)

Uganda v Kapukomo 2017 UGHCCRD 127 (28 September 2017)

Uganda v Karibu 2013 UGHCCRD 32 (9 September 2013)

Uganda v Kasadha 2011 UGHCCRD 72 (12 November 2013)

Uganda v Kasibante 2016 UGHCCRD 27 (29 April 2016)

Uganda v Kasoro 2013 UGHCCRD 42 (11 September 2013)

Uganda v Kasule 2011 UGHCCRD 49 (1 October 2013)

Uganda v Katerega 2016 UGHCCRD 1 (13 April 2016)

Uganda v Kayinga 2016 UGHCCRD 30 (19 May 2016)

Uganda v Kidyel 2014 UGHCCRD 84 (22 August 2014)

Uganda v Kigoye 2013 UGHCCRD 25 (13 May 2013)

Uganda v Kiwalabye 2016 UGHCCRD 79 (2 August 2016)

Uganda v Kiwanuka Kiggundu 2014 UGHCCRD 22 (17 February 2014)

Uganda v Kizuri 2011 UGHCCRD 55 (2 October 2013)

Uganda v Kule 2017 UGHCCRD 41 (10 March 2017)

Uganda v Kunyoma 2014 UGHCCRD 76 (7 August 2014) 
Uganda v Layoor 2014 UGHCCRD 70 (29 September 2014)

Uganda v Logit 2014 UGHCCRD 66 (1 October 2014)

Uganda v Lokut 2017 UGHCCRD 130 (29 September 2017)

Uganda v Lolem 2017 UGHCCRD 126 (30 September 2017)

Uganda v Lomerimoe 2017 UGHCCRD 131 (30 September 2017)

Uganda $v$ Longole 2016 UGHCCRD 18 (25 July 2016)

Uganda v Longori 2017 UGHCCRD 132 (27 September 2017)

Uganda v Lopeyok 2014 UGHCCRD 67 (30 September 2014)

Uganda v Lorapo 2014 UGHCCRD 69 (1 October 2014)

Uganda $v$ Lubowa 2016 UGHCCRD 31 (16 May 2016)

Uganda $v$ Lukwago 2016 UGHCCRD 33 (16 May 2016)

Uganda v Madolo 2016 UGHCCRD 145 (10 March 2016)

Uganda v Maku 2014 UGHCCRD 16 (22 January 2014)

Uganda v Maliya 2016 UGHCCRD 67 (23 August 2016)

Uganda v Mewuva 2013 UGHCCRD 36 (10 September 2013)

Uganda v Mpala 2011 UGHCCRD 75 (13 November 2013)

Uganda v Mugamba 2013 UGHCCRD 101 (27 August 2013)

Uganda v Munguriek 2017 UGHCCRD 53 (19 April 2017)

Uganda v Musana 2014 UGHCCRD 51 (24 June 2014)

Uganda v Musobo 2014 UGHCCRD 08 (14 January 2014)

Uganda v Ndayabaze 2013 UGHCCRD 43 (11 September 2013)

Uganda v Ndyabalema 2016 UGHCCRD 38 (16 May 2016)

Uganda v Ngobi Alias Karadio 2011 UGHCCRD 71 (11 November 2013)

Uganda v Nguche 2014 UGHCCRD 42 (16 May 2014) 
Uganda v Nkwasibwe 2016 UGHCCRD 39 (19 May 2016)

Uganda v Noar 2016 UGHCCRD 72 (30 August 2016)

Uganda v Nyingaling 2017 UGHCCRD 31 (6 February 2017)

Uganda v Ocitti 2015 UGHCCRD 2 (9 March 2015)

Uganda v Odipio 2016 UGHCCRD 132 (23 December 2016)

Uganda v Odong 2017 UGHCCRD 134 (29 September 2017)

Uganda v Odumuna 2013 UGHCCRD 95 (19 December 2013)

Uganda v Ogama 2017 UGHCCRD 11 (2 August 2017)

Uganda v OJ 2017 UGHCCRD 6 (12 January 2017)

Uganda v Ojara 2015 UGHCCRD 6 (9 March 2015)

Uganda v Ojengo 2013 UGHCCRD 77 (13 November 2013)

Uganda v Okello 2017 UGHCCRD 68 (19 April 2017)

Uganda v Okoku 2017 UGHCCRD 8 (4 August 2017)

Uganda v Okongor 2013 UGHCCRD 97 (12 December 2013)

Uganda v Okorimo 2017 UGHCCRD 82 (4 May 2017)

Uganda v Okumu 2017 UGHCCRD 52 (19 April 2017)

Uganda v Okumu Wilfred 2017 UGHCCRD 59 (19 April 2017)

Uganda v Okwairwoth 2017 UGHCCRD 9 (4 August 2017)

Uganda v Okwere 2017 UGHCCRD 57 (19 April 2017)

Uganda v Olega 2016 UGHCCRD 58 (22 August 2016)

Uganda v Olego 2016 UGHCCRD 51 (12 August 2016)

Uganda v Olowo Kamala 2013 UGHCCRD 11 (26 March 2013)

Uganda v Olupot 2017 UGHCCRD 78 (5 May 2017)

Uganda v Omirambe 2016 UGHCCRD 14 (25 July 2016) 
Uganda v Omirambe 2016 UGHCCRD 83 (25 July 2016)

Uganda v Omirambe 2016 UGHCCRD 130 (23 December 2016)

Uganda v Ongiertho 2016 UGHCCRD 52 (11 August 2016)

Uganda v Onyait 2017 UGHCCRD 89 (4 May 2017)

Uganda v Onzima 2017 UGHCCRD 104 (28 June 2017)

Uganda v Opakrwoth 2017 UGHCCRD 50 (19 April 2017)

Uganda v Opolot 2017 UGHCCRD 90 (26 April 2017)

Uganda v Orem 2010 UGHCCRD 50 (1 October 2013)

Uganda v Orombi 2017 UGHCCRD 58 (19 April 2017)

Uganda v Orone 2016 UGHCCRD 107 (13 September 2016)

Uganda v Osipira 2013 UGHCCRD 98 (30 October 2013)

Uganda v Owacha 2016 UGHCCRD 128 (23 December 2016)

Uganda v Owekonimungu 2017 UGHCCRD 19 (7 August 2017)

Uganda v Owilli 2017 UGHCCRD 136 (26 September 2017)

Uganda v Owori 2016 UGHCCRD 2 (13 April 2016)

Uganda v Oyirwoth 2017 UGHCCRD 64 (19 April 2017)

Uganda v Serubogo 2016 UGHCCRD 143 (24 April 2016)

Uganda v Sizomu 2016 UGHCCRD 141 (20 April 2016)

Uganda v Ssali 2016 UGHCCRD 144 (7 April 2016)

Uganda v Ssekamate 2016 UGHCCRD 42 (29 April 2016)

Uganda $v$ Ssemaganda 2016 UGHCCRD 43 (19 May 2016)

Uganda v Ssemanda 2016 UGHCCRD 44 (28 April 2016)

Uganda v Tibagwa 2013 UGHCCRD 41 (10 September 2013)

Uganda v Tugume 2017 UGHCCRD 115 (21 August 2017) 
Uganda v Tumuheki 2016 UGHCCRD 123 (19 October 2016)

Uganda v Tumusiime 2016 UGHCCRD 3 (13 April 2016)

Uganda v Tumusiime 2017 UGHCCRD 15 (23 January 2017)

Uganda v Tumusiime 2017 UGHCCRD 23 (7 August 2017)

Uganda v Tumwesigye Ziraba 2011 UGHCCRD 81 (3 December 2013)

Uganda v Tweshimye 2017 UGHCCRD 16 (23 January 2017)

Uganda v Tyeka 2017 UGHCCRD 23 (6 February 2017)

Uganda v Wacha 2015 UGHCCRD 75 (25 February 2015)

Uganda v Wadri 2017 UGHCCRD 10 (7 August 2017)

Uganda v Waiga 2016 UGHCCRD 86 (6 October 2016)

Uganda $v$ Walyanda 2011 UGHCCRD 11 (16 January 2014)

Uganda v Wanja 2014 UGHCCRD 19 (22 January 2014)

Uganda v Wasolo 2014 UGHCCRD 24 (13 March 2014)

Uganda v Wetokho 2017 UGHCCRD 48 (21 February 2017)

Uganda $v$ Yindu 2016 UGHCCRD 70 (31 August 2016)

Wanasolo v Uganda 2015 UGHCCRD 11 (19 October 2015)

Yali v Uganda 2017 UGHCCRD 107 (15 June 2017) 